\title{
LAZZARO FELICE, EL HÉROE SANTO DE ALICE ROHRWACHER
}

\author{
Teresa Rodríguez Hage \\ Universidad de La Laguna
}

\section{RESUMEN}

Partiendo de la premisa de que Lazzaro Felice (2018), de la cineasta italiana Alice Rohrwacher nace de una visión del mundo que hunde sus raíces en la tradición cristiana y, por tanto, se comprende mejor desde la perspectiva religiosa, analizaremos los diferentes elementos narrativos y estéticos del film, centrándonos en la creación del personaje central, Lazzaro, que, con una poderosa carga espiritual de resonancias cristológicas, es la clave esencial para la interpretación del film. Sin embargo, la lectura religiosa no se agota en su figura, por lo que identificaremos también las numerosas referencias cristianas (iconográficas, sonoras y narrativas) reconocibles en la puesta en escena y nos detendremos en algunos fragmentos del film que revelan cómo las elecciones formales de la directora traducen al lenguaje visual y sonoro la presencia de lo sagrado en la vida cotidiana.

Palabras Clave: Lazzaro Felice, Alice Rohrwacher, cine religioso, cine y religión, cine de mujeres, cine italiano, cine contemporáneo.

\section{LAZZARO FELICE, THE ALICE ROHRWACHER'S HOLY HERO}

\section{Abstract}

Starting from the premise that Lazzaro Felice (2018) by the Italian filmmaker Alice Rohrwacher is born from a vision of the world that has its roots in the Christian tradition and, therefore, is better understood from a religious perspective, we will study the different narrative and aesthetic aspects of the film, focusing on the creation of the central character, Lazarus, who, with a powerful spiritual charge of Christological resonances, is the essential key to the interpretation of the film. However, the religious approach is not limited to his figure, so we will also identify the numerous Christian references (iconographic, sound and narrative) recognizable in the staging and finally, we will discover some fragments of the film which reveals how, the director's formal choices seek to translate into visual and sound language the presence of the sacred in everyday life.

Keywords: Lazzaro Felice, Alice Rohrwacher, religious cinema, Religion in film, female filmmakers, women directors, contemporary films. 
Erial de perplejidad, en los ardientes laberintos; perdidos, entre brillantes estrellas, en esta tediosísima ceniza, ;perdidos! Recordando sobrecogidos, buscamos el gran lenguaje olvidado, el perdido sendero que conduce al cielo, una piedra, una hoja, una puerta ignota. ¿Dónde? ¿Cuándo?

El ángel que nos mira, Thomas Wolfe

De cierto os digo, si no os volvéis y os hacéis como niños, no entraréis en el reino de los cielos.

Mateo 18, 3

\section{CINE Y CRISTIANISMO}

El diálogo entre cine y religión se ha venido entablando desde la aparición del cinematógrafo, que rápidamente se convirtió en uno de los medios de expresión artística más valiosos tanto para la representación naturalista de temas bíblicos como para la plasmación de ideas más espirituales o metafísicas sobre la búsqueda de lo trascendente. Las aproximaciones al fenómeno religioso que ha dado la historia del cine suelen clasificarse en las categorías clásicas de cine comercial y cine de autor o independiente: las propuestas más comerciales basadas bien en las narraciones del Antiguo y Nuevo Testamento (como ejemplo, las cuantiosas versiones sobre la figura de Jesús de Nazaret), o bien las inspiradas en las biografías de personajes del mundo religioso: santos, sacerdotes, predicadores, misioneros, papas, etc., con claro enfoque en las audiencias y escaso interés en plantear cuestiones espirituales. Y, por otro lado, las propuestas más personales de cineastas que quieren transmitir su visión del mundo y su búsqueda de sentido en lo trascendente a través de formulaciones estéticas menos ortodoxas, directores cuya indagación en "lo sagrado" remite a experiencias interiores que expresan con un lenguaje más abstracto, simbólico o metafórico, hablamos de la obra de cineastas como Tarkovski, Dreyer, Bresson, Bergman, Buñuel, Fellini o, más recientemente, Malick. En este espacio más hondamente religioso ubicamos la obra de la italiana Alice Rohrwacher.

Nuestro trabajo plantea que la película Lazzaro Felice (2018), de la cineasta Alice Rohrwacher, nace de una visión del mundo de raíces cristianas y, por tanto, se comprende mejor desde la perspectiva religiosa. Partiendo de esta premisa, analizaremos los diferentes elementos narrativos y estéticos del film, centrándonos en la creación del personaje central, Lazzaro, que, con una poderosa carga espiritual de resonancias cristológicas, es la clave esencial para la interpretación del film. Sin embargo, la lectura religiosa no se agota en su figura, por lo que identificaremos también las numerosas referencias cristianas (iconográficas, sonoras y narrativas) reconocibles en la puesta en escena y, finalmente, nos detendremos en algunos fragmentos del film que revelan cómo las elecciones formales de la directora traducen al lenguaje visual y sonoro la presencia de lo sagrado en lo cotidiano, lo cual expresa a través de una estética de enorme carga poética que aparece de forma súbita en varios momentos de la película y que algunos autores han querido asociar al «realismo mágico». Sin embargo, este estilo literario cuya finalidad es ofrecer, a través de un exuberante lenguaje, un mundo desbordante de fantasía y magia poco tiene 


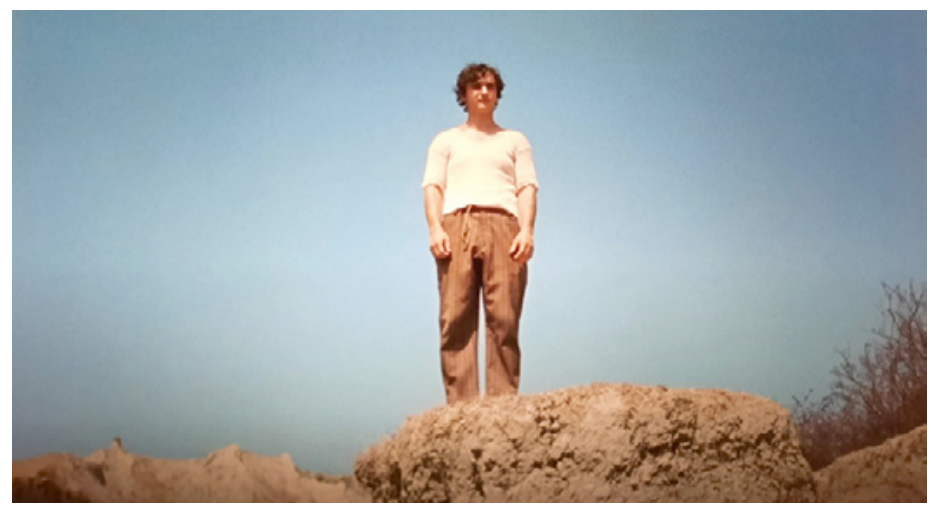

Fig. 1. Lazzaro en un plano del film que recuerda por su angulación y composición a otro similar del personaje de Johannes en el film Ordet (1955), de C.T. Dreyer. Fotograma de Lazzaro Felice.

que ver con las búsquedas espirituales que plantea la película de Rohrwacher, cuyo estilo prescinde totalmente de lo espectacular y de lo fantástico. Con una mirada honesta y clara que se expresa a través de un estilo realista y lírico a un tiempo, dentro de la tradición de los grandes maestros del cine italiano, Rohrwacher logra establecer una poderosa conexión espiritual con el espectador en una película que se revela como una apasionada búsqueda de Dios en un mundo que se desmorona.

\section{EL CARTEL DE LAZZARO FELICE}

El cartel de Lazzaro Felice ofrece una reinterpretación de la misteriosa pintura Gilles (1718 o 1721), de Watteau, también llamada Pierrot (personaje de la Comedia Italiana del Arte). La elección de esta obra del rococó francés como inspiración del póster de la película es toda una declaración de intenciones. Lo analizamos en detalle: Lazzaro ocupa en el cartel el mismo lugar central que Gilles en la obra pictórica, presenta la misma expresión triste y melancólica, idéntica atmósfera poética e irreal lo rodea. Al paisaje de fondo en la pintura, el cartel del film agrega la ciudad, escenario de la segunda parte de la cinta. Se han suprimido los comediantes de la obra pictórica que se encuentran a la espalda de Gilles y el asno ha sido sustituido por el lobo (personaje simbólico del film). Gilles representa a uno de los zanni (sirviente), personajes que en la comedia italiana conducían la obra. Lazzaro es el sirviente en la aldea de Inviolata y también constituye el eje de la narración en el film. La elección de esta obra no es casual, ya que a pesar de representar a un personaje de la comedia italiana, este Pierrot no es el alegre y divertido payaso que ha sido retratado por otros artistas. Rohrwacher ha elegido al melancólico Gilles de Watteau, a quien el prestigioso crítico de arte László Földényi (2004) compara con Cristo: «Da la impresión de que Watteau lo pintó de entrada con la intención de transmitir lo invisible, de hacer aparecer, pictóricamente, lo que no puede pintarse... 


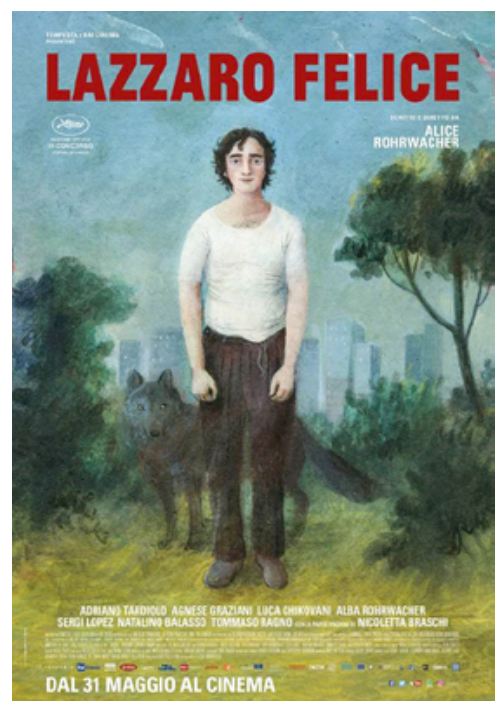

Fig. 2. Cartel de Lazzaro Felice. Dosier prensa Festival de Cannes, 2018.

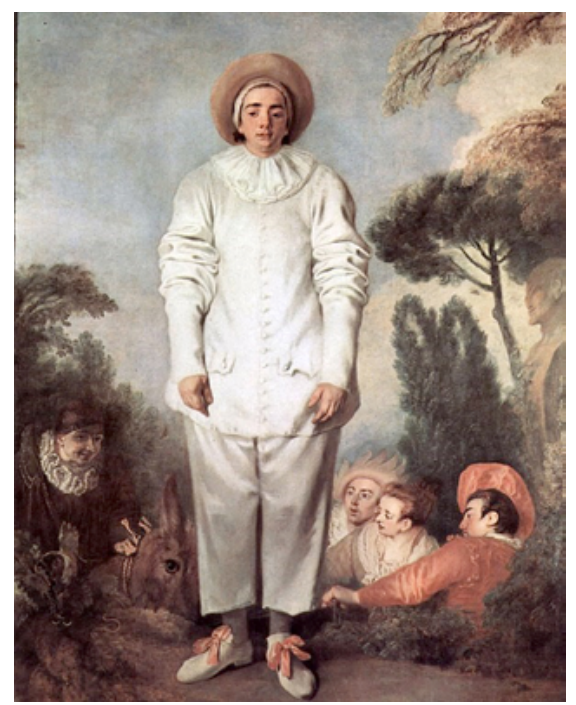

Fig. 3. Gilles (1721), A. Watteau. Obras maestras de la pintura, Madrid, Planeta, 1983.

Gilles es al mismo tiempo figurante y protagonista de lo invisible. Lo encarna y lo padece (paralelismo con Cristo)».

\section{INVIOLATA, LA ALDEA DONDE HABITA DIOS}

En su primera película, Corpo celeste (2011), la directora italiana ya había hecho una profunda indagación espiritual a través de su protagonista, Marta, una adolescente de 13 años, que ante la inminencia del sacramento de la confirmación se enfrenta a una demoledora búsqueda interior. Sobre esta primera exploración del mundo religioso la propia Rohrwacher decía: «El catolicismo en mis películas es una presencia constante, funciona más como una conciencia. En Corpo celeste es muy fuerte su presencia porque en Italia siempre ha sido clara la tensión que existe entre el deseo de una comunidad por unirse alrededor de la religión y la imposibilidad de lograrlo» (Atehortúa, 2021).

Su segundo largometraje, Le meraviglie (2014), que obtuvo el Gran Premio del Jurado en el Festival de Cannes de ese año, se centra en la historia de un matrimonio con cuatro hijas que se dedican a la explotación apícola en una granja de la Toscana, lo que le sirve para seguir ahondando en los conflictos familiares, las complicaciones de la adolescencia, las contradicciones entre tradición y modernidad y entre la vida rural y urbana, temas que también aborda en Lazzaro Felice (2018), su película más premiada. El año de su estreno consigue varios galardones: Mejor 


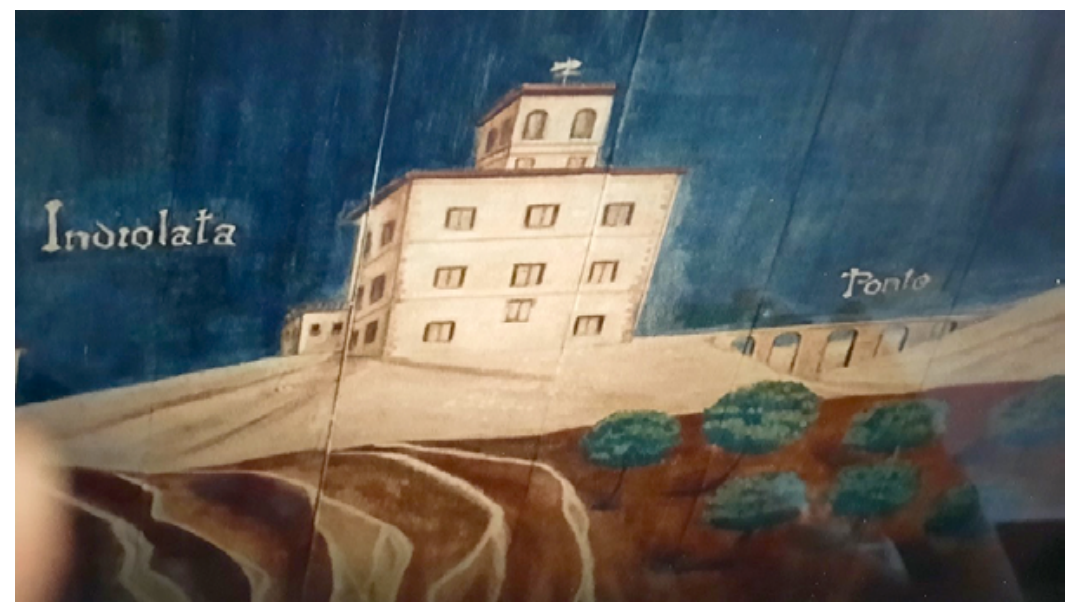

Fig. 4. Fotograma de la película que muestra un antiguo cuadro de Inviolata con el puente (aún en pie) que unía la aldea a la civilización.

Guion en el Festival de Cannes, Premio Cummings a la Mejor Película en el Festival Internacional de Cine de Jerusalén, Premio Especial del Jurado en el Festival de Sitges, Mejor Película Extranjera en el National Board of Review y numerosas nominaciones en distintos festivales internacionales de cine.

La película narra la historia de Lazzaro (interpretado por Adriano Tardiolo), un joven campesino de extrema bondad que vive en una aldea interior de Italia llamada Inviolata, un lugar aislado de la civilización donde los campesinos trabajan para la marquesa Alfonsina de Luna (la actriz Nicoletta Braschi) en un sistema de aparcería ya abolido que ésta oculta a sus jornaleros, quienes la consideran propietaria incluso de sus propias vidas. Los campesinos son vilmente explotados por la marquesa y al mismo tiempo ellos explotan a Lazzaro, aprovechándose de su candorosa ingenuidad. Un verano la marquesa trae consigo a su hijo Tancredi (que interpreta Luca Chikovani), un joven imaginativo y rebelde que se aburre en el hogar familiar. En la hacienda conoce al inocente Lazzaro y nace entre ellos una bonita amistad adolescente. «Una amistad tan preciosa», revela la directora, «que le permitirá a Lazzaro atravesar el tiempo y llegar al mundo moderno en busca de su amigo» (Tempesta Film, 2018).

Inviolata (la aldea «intocada») simboliza, en cierto modo, un paraíso perdido, la forma de vida campesina, hoy casi desaparecida en Italia. De ahí que se nos muestra como un lugar aislado del mundo, no sólo espacialmente (ya que el puente que lo unía a la civilización está derribado), sino temporalmente: los campesinos parecen habitar en una edad perdida, lejana, viviendo al ritmo de la siembra y la cosecha.

Desde el punto de vista técnico, la película se filma en $16 \mathrm{~mm}$, lo que aporta ciertas imperfecciones expresivas que transmiten mayor naturalidad a las imágenes. 


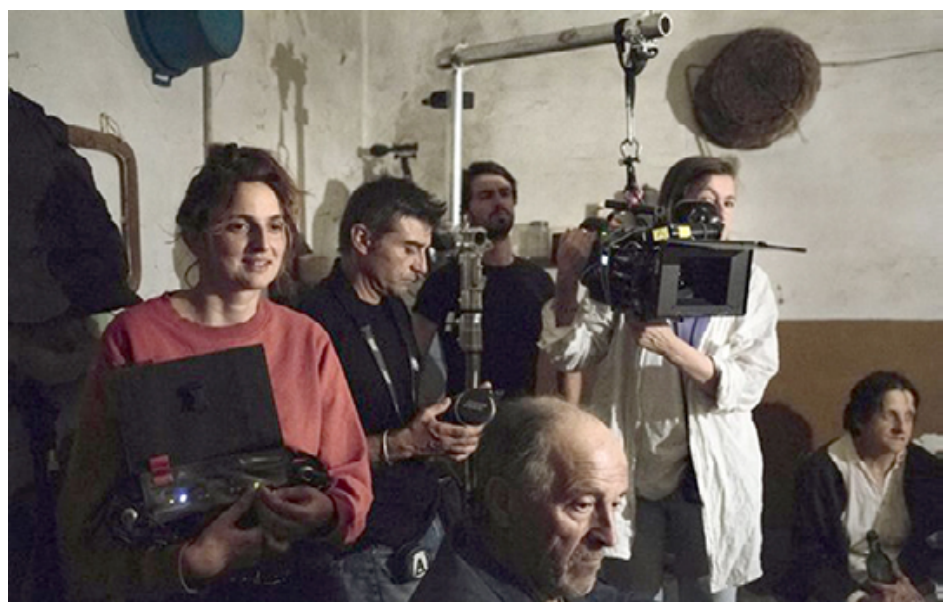

Fig. 5. Alice Rohrwacher en un momento del rodaje.

A este respecto se expresa también la directora de fotografía de la película, Hélène Louvart:

Este medio aporta algo orgánico, artesanal, que corresponde a una forma de ver el mundo un poco diferente. El renderizado del Super 16 desprende una forma de poesía, de «fiebre de la imagen» y nos gusta la sensación de estar siempre un poco sorprendidas por el renderizado de las imágenes, a veces demasiado oscuro o demasiado brillante, poco nítido o granulado. Un poco como si no domináramos por completo esta herramienta, pero las imperfecciones de este formato finalmente le darán un significado visual a la película, un deseo que no busca controlarlo todo de manera sistemática (AFS, 2018).

Por su parte, el guion de la película encuentra su origen en un hecho real que Alice Rohrwacher había leído en la prensa italiana:

Esta [película] también está relacionada con el hecho de que leí un artículo de un periódico cuando era bastante joven que decía que había una marquesa que había mantenido a algunos de sus aparceros como aparceros sin informarles, aprovechando lo ingenuos que eran. Entonces, cuando finalmente me ofrecieron la oportunidad de estar en el programa del Cineasta en Residencia del Festival de Cine de Nueva York, tuve la distancia suficiente para mirar todo eso y escribir sobre ello (Saito, 2018).

«¿No tienes miedo de que descubran la verdad?», pregunta Tancredi a su madre en un momento de la película. "Los seres humanos son como animales. $\mathrm{Si}$ los liberas, serán conscientes de su condición de esclavos y se sumirán en la miseria. Ahora sufren también pero no lo saben", responde la marquesa sin el menor escrúpulo. Luego, observando desde la ventana a Lazzaro, añade: «Mira, ¿lo ves?, yo me 


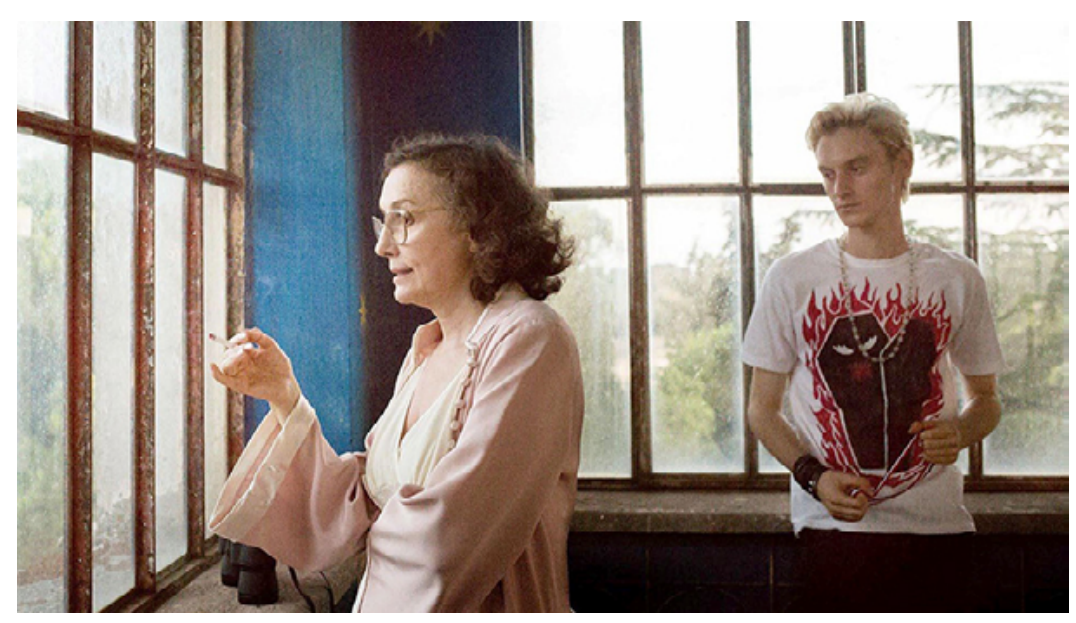

Fig. 6. La marquesa de Luna y su hijo Tancredi hablan sobre la explotación humana en una escena del film. Fotograma de la película.

aprovecho de ellos y ellos se aprovechan de él. Es una cadena, no se puede parar». «A lo mejor él no se aprovecha de nadie», dice su hijo, que mira con simpatía a Lazzaro.

La historia se estructura en dos partes: la primera ubicada en un espacio rural en la década de los ochenta del siglo pasado y, tras un suceso inesperado que revela la realidad de su condición a los aparceros, la acción se traslada a la periferia urbana unos veinte años después. Saltamos en un instante de la Italia rural a la Italia urbana, la explotación de la aristocracia terrateniente de la sociedad preindustrial ha sido sustituida por la de los poderes financieros del capitalismo. Las víctimas continúan siendo los campesinos, reconvertidos ahora en vagabundos del extrarradio urbano que malviven a base de pequeńos robos sumidos en la miseria, como había vaticinado, no sin cierta ironía del guion, la marquesa. Su situación no ha mejorado, han pasado de la condición de "esclavos» de la nobleza campesina a la de «esclavos» de la sociedad del progreso. Sus creencias religiosas han sido reemplazadas por el culto a la televisión y a la comida basura. La película muestra la miseria material y moral de los personajes, el ser humano no ha evolucionado en la era del capitalismo, se ha vuelto más pícaro y se ve obligado a delinquir para poder sobrevivir. Sólo Lazzaro, inocente y atemporal, permanece ajeno al mundo miserable que le rodea. Lazzaro constituye el nexo entre pasado y presente, entre lo rural y lo urbano, entre los nobles y los campesinos, entre la alegría estival y la crudeza del invierno. Cuando el mundo de los personajes se vuelve frío y oscuro, cuando el universo idílico de Inviolata se derrumba, la película nos muestra un resquicio de esperanza. La inocencia de Lazzaro revela que hay algo más allá del dolor y del esfuerzo humanos, algo que nos viene dado y que sólo se puede percibir espiritualmente.

«Inicié la escritura pensando el contexto, el momento apocalíptico, la crítica que tenía que llevar la historia. Y posteriormente entendí que el protagonista tenía que 


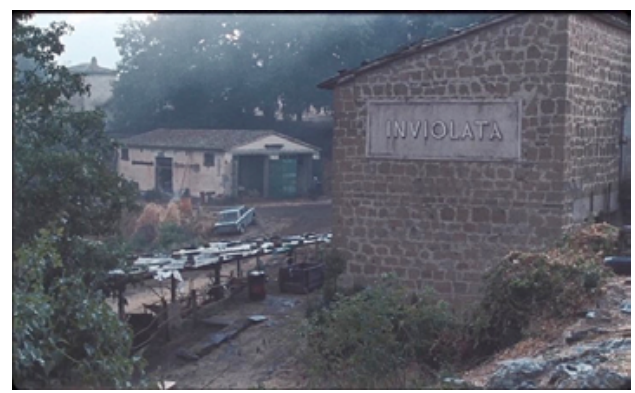

Fig. 7. La hacienda de Inviolata donde viven hacinados los campesinos. Fotograma del film.

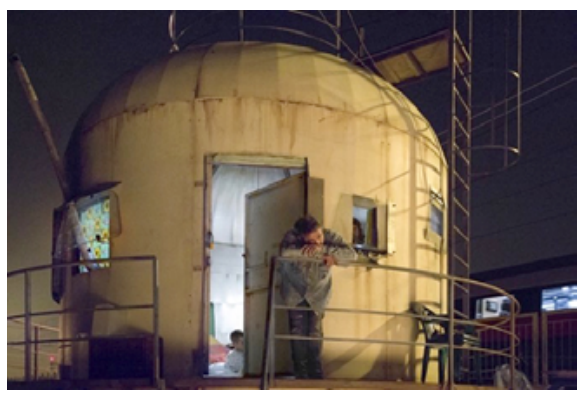

Fig. 8. El hogar en el que habitan los personajes en la ciudad es un viejo y abandonado tanque industrial. Fotograma del film.

ser un hombre bueno, este Lazzaro que dedica mucho tiempo a ayudar a los demás, a una bonhomía que atraviesa el tiempo». Sobre la explotación del ser humano por el ser humano, la directora lo tiene claro: «Es una historia clásica, ¿verdad? Y el mundo cambia, se transforma y el ser humano sigue idéntico» (entrevista a Rohrwacher en Belinchón, 2018).

Por otro lado, la directora italiana refiere la devastación humana que supuso en su país el éxodo casi forzoso del campo a la ciudad de miles de campesinos.

La tragedia que ha devastado a mi país, a saber, el paso de una Edad Media histórica a una edad media humana: el final de la civilización rural, la migración a los límites de la ciudad de miles de personas que no conocían nada de la modernidad (Tempestá, 2018).

La película es susceptible de diferentes e interesantes lecturas: histórico-política (Andi, 2019), sociológica (Guardiola, 2019), filosófica (Cavalcanti, 2020), ecológica (Di Bianco, 2020), etc., que vendrían determinadas por sus propias dicotomías argumentales: pasado y presente, vida rural y urbana, feudalismo y capitalismo, lucha de clases y también por las muchas confluencias temáticas o subtextos: las injusticias sociales, la alegría de la amistad adolescente, el núcleo familiar y la pertenencia a la comunidad, el éxodo del campo a la ciudad, el problema de la inmigración, la explotación humana, etc., pero además de la evidente denuncia sociopolítica que hace Rohrwacher y de su visión más bien pesimista de la historia y de la condición humana (muy cercana a la de Buñuel, especialmente la que mostró en su tratamiento de los mendigos en Viridiana), Lazzaro Felice reclama una lectura religiosa. Una película que sugiere que la única salida a ese mundo agotado, miserable e injusto que se pone ante nuestros ojos se encuentra en "mirar» de una manera pura como hace Lazzaro; una película que establece correlaciones entre el mundo exterior e interior del ser humano, entre lo racional y lo espiritual, lo visible y lo invisible, que evoca el «misterio», el mundo de lo sublime y lo inexplicable; una película que se pregunta sobre el sentido del sufrimiento; una película, en definitiva, que logra 


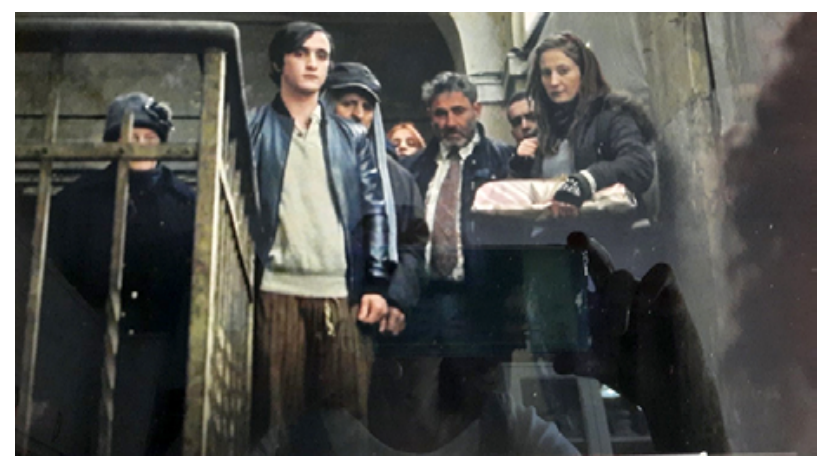

Fig. 9. En la ciudad, los personajes acuden a la cita con Tancredi. En primer plano los actores Adriano Tardiolo (Lazzaro), Sergi López (Ultimo) y Alba Rohrwacher (Antonia adulta).

Fotograma de la película.

alcanzar zonas profundas del alma humana es, no cabe duda, una película religiosa. Una película inspirada, según su autora, en una religión que une a la humanidad espiritualmente, no en una religión oficial:

Creo que si un santo apareciera hoy con una llamada a otra forma de existir, si apareciera en nuestras vidas modernas, tal vez ni siquiera lo reconoceríamos o tal vez nos libraríamos de él, sin pensarlo. Estamos hablando aquí de una religión de la humanidad, no de una religión oficial bien administrada con sus vestiduras deslumbrantes y sus reglas semanales (Tempesta Film, 2018).

Lazzaro Felice propone pues otra forma de existir, otra forma de «mirar el mundo», propone abiertamente que tomemos a Lazzaro como modelo y Lazzaro, que encarna la bondad suprema, remite de manera directa a la figura de Cristo, como ya lo había hecho en la literatura rusa otro inolvidable personaje, con quien Lazzaro tiene más de una conexión, el príncipe Mishkin de la novela El idiota (1868) de Dostoievski. Lazzaro y el inocente Mishkin son personajes a través de los cuales se nos invita a emprender un nuevo camino, a renovarnos, a inventar una nueva humanidad. Lazzaro Felice es una profunda reflexión sobre la sociedad, sobre el ser humano en la historia y sobre su relación con lo sagrado. La imagen luminosa del protagonista atenúa, en cierto modo, la degradación humana de sus compañeros de viaje mirados con crudo realismo, pero también con ternura por la directora italiana. A este respecto es interesante señalar, con Greeley (1988), que la teología católica, al contrario de la opinión generalizada, ve la naturaleza humana como «desvalida» más que como "pecadora», así ve también Rohrwacher a sus personajes, a esos pobres campesinos arrojados casi por la fuerza a la metrópoli donde intentan sobrevivir como desahuciados en un desolador paisaje material y humano.

Lazzaro es también, en cierto modo, un personaje desvalido, lo es para nosotros como espectadores pero él no se siente así en modo alguno. Lazzaro es 


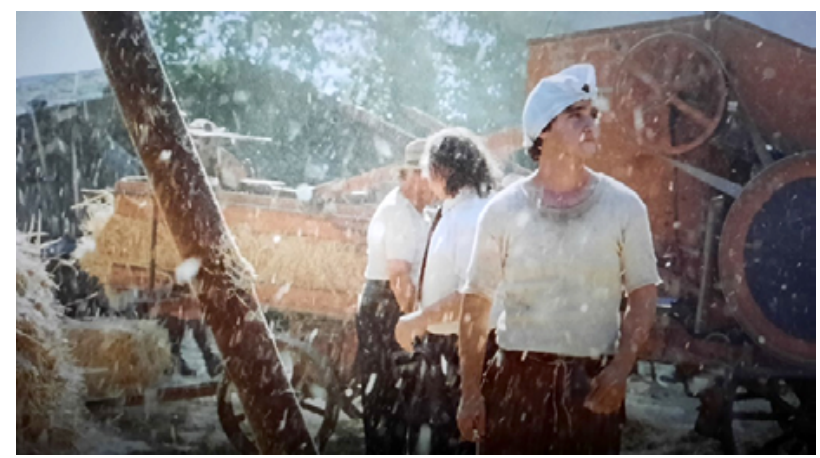

Fig. 10. Lazzaro en un momento de la cosecha. Fotograma de la película.

feliz porque su inocencia es como la de un niño, no tiene conciencia de su felicidad porque es su propia naturaleza, la fuerza del personaje reside en la pureza con que mira al mundo que le rodea. En este sentido, Lazzaro ha sido creado, afirma la directora, para "ser mirado, es difícil que podamos identificarnos con un santo [...] Una película en la que, si se sufre, no es porque se sea el protagonista, sino porque lo estás mirando" (Atehortúa, 2021). Lazzaro es diferente a los demás, es un personaje contrapuesto a los otros porque es un ser extraordinariamente ingenuo, sin malicia, un ser puro, espiritual. Los campesinos se aprovechan de esa ingenuidad, es su pretexto para explotarlo. En Inviolata es el sirviente de todos, le exigen que lleve a cabo todas las tareas: sembrar, recolectar, cargar y descargar la cosecha, trasladar las mercancías, los enseres, ocuparse de las gallinas, de las ovejas, traer y llevar a la abuela... pero a Lazzaro no le importa, no se cansa, no protesta, es «manso y humilde de corazón» como Jesús.

\section{DEL RELATO PASTORIL A LA LEYENDA DEL LOBO}

El personaje de Lazzaro aparece como imagen inicial del largometraje, en la oscuridad de la noche. Le preceden los títulos de crédito sobre fondo negro, se escucha el canto de los grillos y voces y risas de los campesinos, luego se oye: «Lazzaro", y los créditos abren a un plano general donde vemos al muchacho a las puertas de un granero, sujeta una zampogna ${ }^{1}$. "¿Ya estás mirando al infinito?», le dice otro personaje que se le acerca, "Vamos, nos están esperando, arréglate el pelo» y dócilmente el joven se deja peinar. La siguiente escena traslada la acción de nuevo a la oscuridad, se oye el llanto de un bebé seguido por la voz de una joven que pide

${ }^{1}$ Gaita típica de la música folclórica del sur de Italia, cuya tradición se remonta a los pueblos pastores de las regiones montańosas. Su uso se relaciona con la Navidad. 


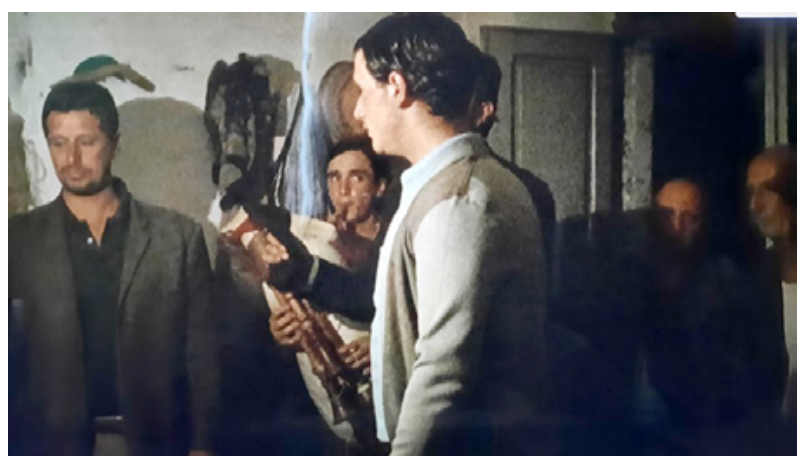

Fig. 11. Los campesinos celebran la fiesta de compromiso. Lazzaro toca la zampogna. Fotograma del film.

un bombillo (vemos que éste se pasa de una a otra estancia, sólo hay uno para toda la casa, reflejo de la pobreza extrema de sus moradores). Se ilumina por fin una habitación y vemos a un grupo de jóvenes como ángeles con sus vestidos claros, su alegría y una luz deslumbrante que dibuja sus figuras y movimientos en el encuadre. Bromean y ríen con la joven enamorada, Mariagrazia (vestida de azul como se suele representar iconográficamente a la Virgen María), a quien destina su canción Giuseppe (José) bajo la ventana. En el exterior, los cantores ofrecen una serenata nocturna, Lazzaro toca la zampogna. El grupo entra en la casa y los labriegos ofrecen lo poco que tienen: un vaso de Marsala y una lata de anchoas que se reparte para todos. Los músicos continúan con la canción, la cámara recorre la modestísima estancia y nos va mostrando los rostros envejecidos de todos los campesinos que comparten la misma morada, austera y humilde. Las imágenes transmiten un realismo casi documental. Y en el recorrido, la cámara da un primer plano a Lazzaro justo cuando Giuseppe entona el verso: «haces a los ángeles bajar del Paraíso». Todos beben del vaso de vino, Lazzaro se coloca el último y cuando llega a él, ya no queda vino. «No importa», dice gentil.

La película se inicia como vemos con una escena nocturna. Rohrwacher explica en una entrevista concedida a Jerónimo Atehortúa (2021) su preferencia por iniciar la narración en la oscuridad:

Para mí, empezar en la noche es poner a los espectadores en un lugar en el que deben usar su imaginación, dejándose afectar por los sonidos, pues aún no saben dónde están, aún están un poco perdidos. De esta manera, nuestra relación empieza mediada por la imaginación. Esto parte del juego que me interesa en una película como espectadora, no solo como directora. También esto es reflejo de mi fascinación por el juego entre la luz y la oscuridad, por las sombras.

A nivel estético, la escena se crea, como dijimos, en clave documental: los aparceros no son actores profesionales sino campesinos de la zona; la cámara muestra sus rostros duros, secos, curtidos por el trabajo; una cámara objetiva, enunciativa, 


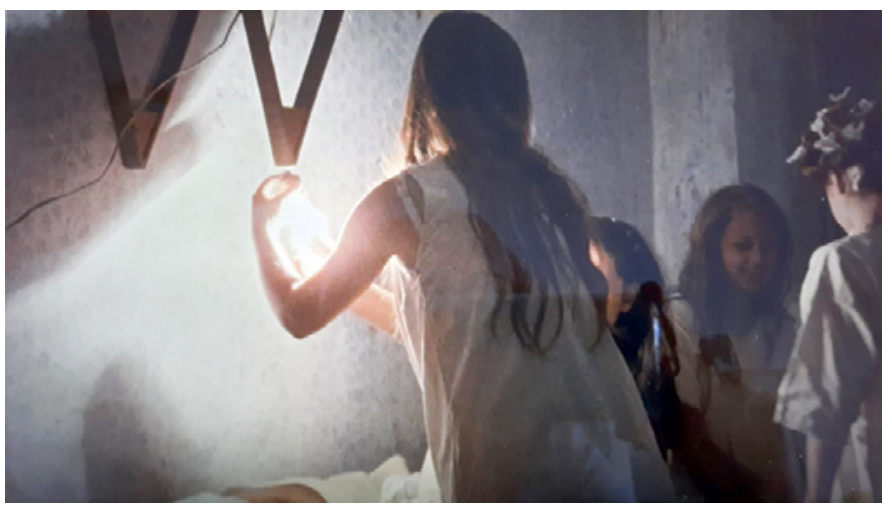

Fig. 12. Las jóvenes de Inviolata encienden la luz en la habitación al escuchar a los músicos bajo la ventana. Fotograma de la película.

que, de vez en cuando, se detiene para mostrar un encuadre de Lazzaro, o de Antonia (la protagonista femenina, interpretada como adolescente por la actriz Agnese Graziani), que le mira, quizá intuye en él algo que los demás no perciben. Luego Giuseppe anuncia que él y Mariagrazia se quieren ir a la ciudad a probar fortuna. La escena se corta con la inquietante aparición de una gallina (anuncio de la amenaza del lobo) a la que la cámara le dedica algunos planos (al más puro estilo Buñuel). A continuación se ordena a Lazzaro que la devuelva al gallinero.

En esta primera secuencia del film, construida en cuatro escenas a modo de prólogo, encontramos varios elementos que remiten a la tradición cristiana del belén ${ }^{2}$ : un bebé que llora, las figuras de María y José reflejadas en los nombres de los jóvenes enamorados Giuseppe y Mariagrazia, iluminados siempre por la luz de la estancia, los alegres ángeles en la ventana, los pastores que cantan al ritmo de la zampogna. En definitiva, la humilde morada de Jesús de Nazaret, que, desde el punto de vista histórico, fue un profeta judío campesino. Por otra parte, aparece también en la referencia al lobo que caza a las gallinas, la primera evocación a la leyenda de san Francisco de Asís y el lobo de Gubbio ${ }^{3}$, que tiene una presencia constante en la película. Cuando Lazzaro llega al gallinero, Carletto, otro labriego que quiere unirse a la fiesta de la casa, le pide que lo sustituya en la guardia del lobo. Lazzaro accede apaciblemente. Se queda solo, más tarde llama a Carletto, que no responde. Entonces se sienta, mira al cielo y dice: «no me oye». Contraplano de la luna (Lazzaro habla a la «hermana luna»). Funde a negro y aparecen los créditos del título de

2 Según la tradición franciscana, el primer belén o pesebre de la historia fue obra de san Francisco de Asís en la localidad de Greccio (Italia) en 1223 (Relato de San Buenaventura, LM, 10, 7).

${ }^{3}$ La leyenda aparece narrada en el anónimo del siglo xiv Las florecillas de San Francisco (I fioretti di San Francesco) en el capítulo xxi: «Cómo San Francisco amansó, por virtud divina, a un lobo ferocísimo». 


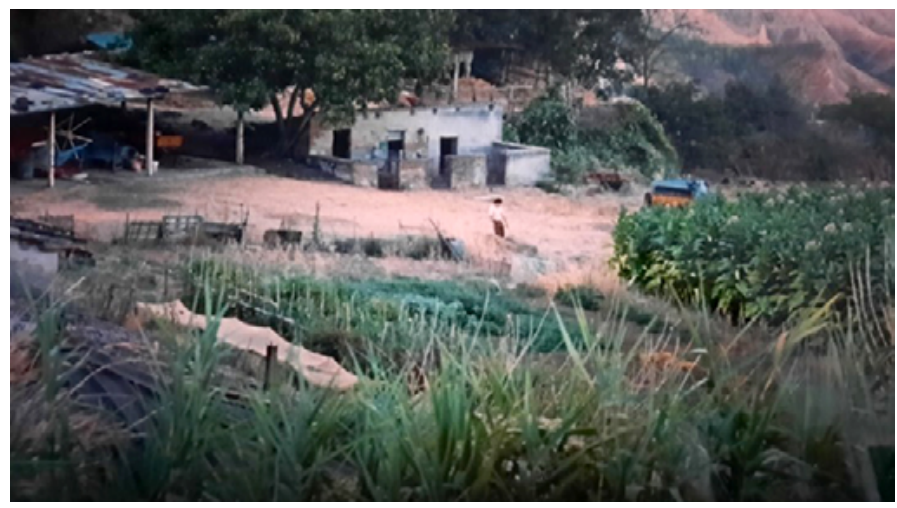

Fig. 13. Lazzaro recoge la cosecha en la hacienda. Fotograma del film.

la película. Este mundo rural de la primera parte de Lazzaro Felice se recreó recuperando una zona agrícola en un lugar cerca de Vetriolo, lo relata Emita Frigato, la directora de escenografía:

En cooperación con los pocos habitantes de Vetriolo, cultivaron tabaco, mes tras mes. Comenzaron un huerto y trajeron gallinas, patos, pavos y otros animales. Después de encontrar una trilladora de la década de 1950 en el granero de un agroturismo local, la restauraron y encontraron agricultores que sabían cómo usarla. Trajeron campesinos de los alrededores de Viterbo para repoblar la Inviolata. «La gente local, algunas de las cuarenta personas que una vez vivieron allí, se emocionó al ver que el lugar volvió a la vida» (Bianco, 2020).

Tras las escenas iniciales de la historia, que comienzan como un apacible relato pastoril, descubrimos que en Inviolata la vida no es tan idílica como parece. A la mañana siguiente, mientras los campesinos hacen la cosecha en la plantación de tabaco, llega Nicola, el administrador de la marquesa, acompañado de un sacerdote que viene a bendecir la nueva cosechadora. Como ha apuntado Hugo Cavalcanti (2020), la Iglesia católica es visiblemente enjuiciada en el film. Efectivamente, el personaje del sacerdote, con su presencia en Inviolata junto al capataz, indica que es conocedor de la explotación que sufren los campesinos y, en consecuencia, la acepta y la consiente. Por su parte, Nicola se nos muestra como un ser despreciable, mientras pide a Lazzaro que descargue la mercancía que ha traído, dice a una campesina, guiñándole el ojo, que el bebé que lleva en los brazos se parece a él (insinúa que es un hijo ilegítimo suyo), después ofrece caramelos a los niños en actitud paternalista y al entrar a la casa, bromea amigablemente con los aparceros para inmediatamente escamotearles sus ganancias: suma los productos de la cosecha pero descuenta a los campesinos lo que les ha traído en la camioneta: «Si a eso le resto el rollo de alambre, la gasolina, las anchoas y los enseres domésticos, pues sale... Pero ¿y los capones?», pregunta. "Los devoró el lobo», responde un campesino. "Con lobo o sin lobo, los capones ya no están. Así que los añado a las deudas. Y con esto, también este mes 


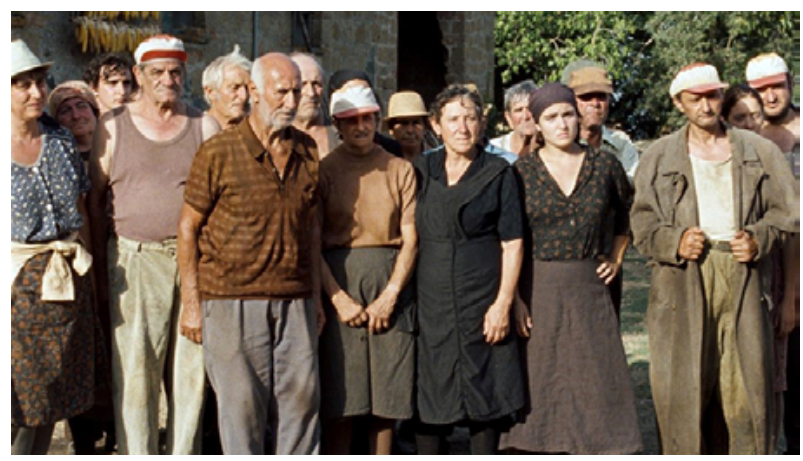

Fig. 14. Los campesinos miran furiosos a Nicola cuando grita que el niño le ha robado el espejo de la moto. Fotograma del film.

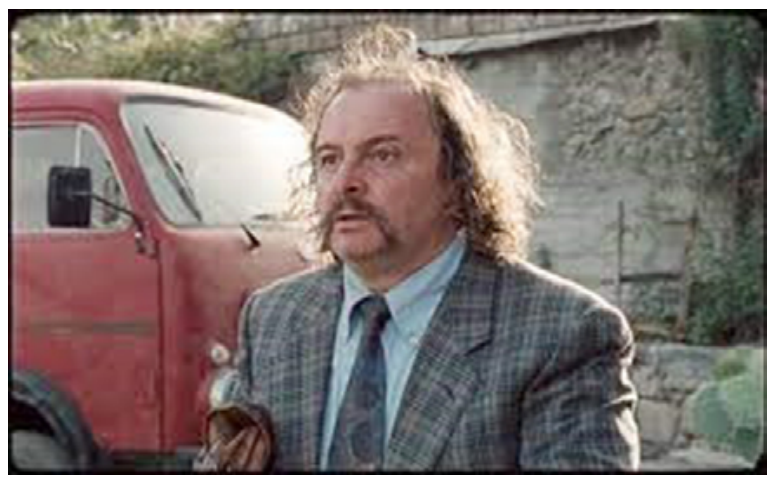

Fig. 15. Nicola, el administrador de la marquesa, mira asustado a los campesinos. Fotograma del film.

sube la deuda», les dice sin el menor reparo. "Vaya, otro mes que hemos trabajado para nada», responde una mujer. «Deberíamos partirle las piernas».

La irrupción en escena del sacerdote gritando que ocurre algo grave los lleva a todos al exterior y vemos a Giuseppe y Mariagrazia subidos a la camioneta con la intención de irse a la ciudad, Nicola se enfada y les dice que no pueden, que tienen que pedir permiso a la marquesa. Un niño sube a su moto jugando, Nicola grita que le ha robado el espejo. Y justamente, como en un juego de espejos, la escena cambia de registro en ese instante: desaparece el sonido natural en la banda sonora y es reemplazado por el de un viento furioso, vemos un plano de los campesinos, que miran firmes y desafiantes al capataz, y otro del capaz asustado. Esta transformación de los recursos expresivos muestra el miedo de Nicola y la furia de los campesinos. El plano del espejo que sostiene el niño en la mano da paso a una inversión de la realidad para revelar el inconsciente de los personajes. El capataz huye a toda prisa y los niños le siguen corriendo tras la moto. Luego la cámara muestra a Lazzaro en 


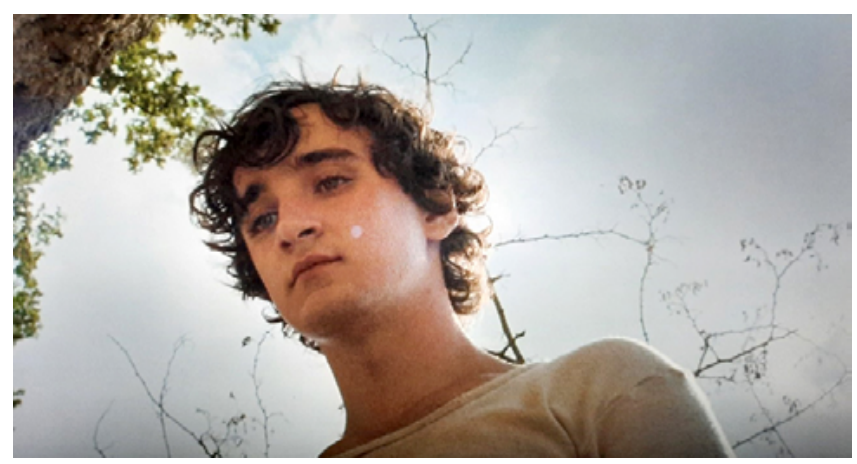

Fig. 16. Lazzaro, un espíritu puro que evoca la figura de Jesús de Nazaret. Fotograma del film.

la camioneta, que va delante de Nicola con el producto de la cosecha, el sonido del viento se mezcla ahora con el aullido del lobo y, finalmente, vuelve el sonido natural de la escena. Ésta es la primera vez que la película nos muestra esa estética personal de Rohrwacher consistente en evocar las emociones humanas de sus personajes a través de la subversión del lenguaje fílmico. Después de este momento poético, la cámara sigue a la camioneta, que se dirige a la casa de la marquesa para descargar la cosecha. Mientras Lazzaro hace el trabajo, el sacerdote lo observa impasible sin prestarle la menor ayuda. Tampoco lo hace Nicola, que lo invita, con total desvergüenza, a volver caminando a la aldea.

\section{LAZZARO, EL HÉROE SANTO DE ALICE ROHRWACHER}

Rohrwacher nos presenta desde el inicio de Lazzaro Felice el retrato de un "siervo de Dios», el retrato de un santo de nuestro tiempo. Para la caracterización de su héroe, la directora toma referencias y elementos del cristianismo. Lazzaro, como habíamos dicho, es símbolo de la bondad suprema y, por tanto, representa la figura de Jesús. Su alma pura conecta con Dios. Es un ser espiritual rodeado de amenazantes lobos que se aprovechan de su inocencia (Mt 10, 16: Yo os envío como ovejas en medio de lobos). Los lobos para Lazzaro son los propios personajes que le rodean, sin embargo, la figura del lobo (alusión franciscana), presentada desde el inicio del film como un peligro para los campesinos, no lo es para el protagonista, como irá revelando la trama.

La caracterización de Lazzaro remite a la figura de san Francisco de Asís y su naturaleza inmaculada parece inspirada en los Evangelios: Lazzaro es el servidor de todos (Mt 20, 28: No he venido ser servido sino a servir); el amigo fiel (Mt 28, 20: Yo estaré con vosotros todos los días, hasta el fin del mundo), el que pone la otra mejilla (Mt 5, 39: No resistáis al que es malo; antes, a cualquiera que te hiera en la mejilla derecha, vuélvele también la otra). Su esencia es bienaventurada (Mt 5, 1-10): Lazzaro 
es manso (Bienaventurados los mansos, porque ellos heredarán la tierra), es pacífico (Bienaventurados los pacificos porque ellos serán llamados hijos de Dios) y es, sobre todo, limpio de corazón (Bienaventurados los limpios de corazón, porque ellos verán a Dios).

Rohrwacher define Lazzaro Felice como una fábula, casi diríamos una parábola por su poderosa dimensión religiosa. Lazzaro es un cordero, ciertamente, pero es el Cordero de Dios (como ha señalado Andi, 2019). Lazzaro es un ser tocado por la "gracia", es la presencia de Dios en la vida cotidiana de los campesinos de Inviolata. Lazzaro simboliza la pureza, "lo sagrado», la luz en la oscuridad que le rodea. En un mundo en el que los personajes sobreviven a duras penas, Lazzaro trabaja incansable, nada le perturba, su mirada es siempre franca e inofensiva. Es una figura salvífica de ecos cristológicos que la directora contrapone a su alrededor para abrir una ventana a la esperanza. Rohrwacher nos invita a mirar el mundo a través de los ojos de Lazzaro, a sumergirnos en él, quizá en esa mirada limpia resida la salvación, quizá en esa mirada podamos encontrar una salida al mundo desesperanzado, descreído e insolidario en que vivimos.

En el plano narrativo, el personaje impacta de igual modo porque carece de raciocinio, percibe el mundo como los niños, su contenido es sólo su alma, conoce el mundo de una manera espiritual, pura, simple, lo que algunos personajes perciben como la «nada». En un momento del film las jóvenes campesinas se burlan de él, la escena se desarrolla en un manantial donde están lavando la ropa cuando aparece Lazzaro: «¿Quién viene?», dice una de las muchachas, y otra responde: «Nadie, Lazzaro».

También, desde el punto de vista formal, la directora emplea un lenguaje que traduce la personalidad transparente de Lazzaro: planos frontales, abiertos, francos como él, a veces ligeros contrapicados lo muestran por encima de nuestros ojos como a un ser que viene «de lo alto». Sobre la manera de enfocar al personaje declara en una entrevista:

En Lazzaro Felice decidimos además no hacer uso de las máscaras del recuadro. Decidimos hacerla con un recuadro abierto. Con Hélène Louvart, la directora de fotografía, tomamos la decisión de no esconder nada, de dejar el cuadro tal y como es, sin hacerle correcciones. Lazzaro es un personaje que no tiene nada que ocultar, así que queríamos darle el mismo tratamiento a la imagen (Atehortúa, 2021).

La cámara le enfoca, por tanto, de manera objetiva, le sigue de cerca, muestra sus limitados movimientos, su robusta figura sin apenas gestualidad, su mirada abierta, su semblante que es todo gentileza y amor, y a veces la cámara lo mira desde lo alto: Dios observa a su Hijo. La directora de fotografía, Hélène Louvart, lo expresa de este modo:

Establecimos tres formas diferentes de filmar, y cada escena solo tenía una o dos de las tres formas de filmar. La primera fue una cámara cercana al hombro que sigue las acciones y los personajes de forma normal y sin ningún punto de vista particular: estamos con Lazzaro y con el grupo de personas, y estamos filmando «justo lo que está pasando frente a nosotros». La segunda es una cámara de pie, fija, panorámica o viajera donde nos acercamos a él, con una distancia focal más 


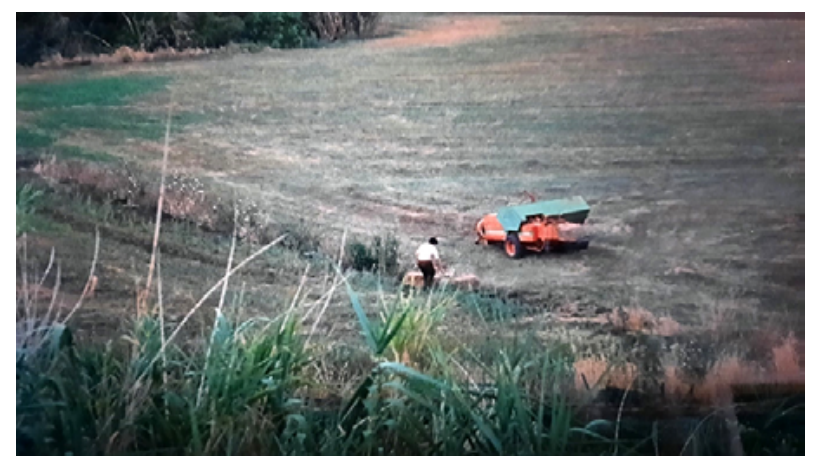

Fig. 17. Lazzaro es observado por la cámara desde lo alto. Dios observa a su Hijo. Fotograma del film.

ajustada que solo encaja a Lazzaro en el grupo; o, incluso si está solo, está «desapegado» del contexto circundante. Generalmente en ángulo bajo. Él está, en cierto modo, «magnificado» por el entorno, es decir, por la forma de mirarlo. Luego, la tercera forma de filmar es una noción de punto de vista que se aleja claramente de la narración, con marcos más amplios y, con mayor frecuencia, en altura. Un poco como una «entidad» observando a Lazzaro (AFC, 2018).

El guion narrativo presenta a Lazzaro con idéntica sobriedad de lenguaje, apenas habla, sus diálogos son muy concisos, su expresión siempre lacónica. Carece de palabras y también de historia: no tiene padres, dice a su amigo Tancredi en un momento del film. Es un personaje al que se priva conscientemente de recursos narrativos que no sean su sola presencia, y esto es así porque Lazzaro, como hemos dicho, es un personaje espiritual cuyo poder radica en su abrumadora simpleza. Su actitud frente al mundo es sincera, generosa, sin malicia, lo que se refleja en su luminoso rostro, el bello rostro de grandes ojos y sonrisa franca de Adriano Tardiolo, que interpreta a Lazzaro con prodigiosa naturalidad como si ambos, actor y personaje, fueran la misma persona. A este respecto, el actor catalán Sergi López (que interpreta a Ultimo, el timador con quien convive Antonia y su familia en los suburbios urbanos) declara en una entrevista (Fernández, 2018): «[Tardiolo] Es una pasada. Desarmante. Podía equivocarse o ponerse nervioso, como cualquier actor profesional, pero luego te daba las gracias o te pedía perdón, te miraba, y te desarmaba. Sí, es un poco como el personaje, pero no tan acentuado». Adriano Tardiolo ha conseguido crear un personaje maravilloso, único, tanto que el espectador experimenta la necesidad de asirse a su alma pura. Rohrwacher construye a su protagonista no sólo para contraponerlo a los que le rodean sino también para ponerlo frente a nosotros como espectadores y sugerirnos que en Él se encuentra la salvación.

El personaje se configura, como venimos diciendo, a partir de referencias cristianas muy directas. Antes que nada, el propio título de la película y el nombre de su protagonista remiten al Evangelio de Juan (Jn 11, 1-45), pasaje donde se relata la resurrección de Lazzaro (hermano de Marta y María de Betania, amigos 


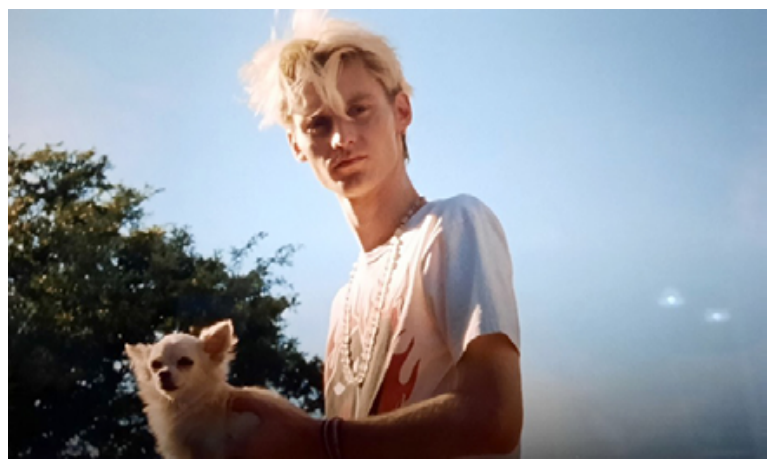

Fig. 18. Tancredi con su perro Ercole. Fotograma del film.

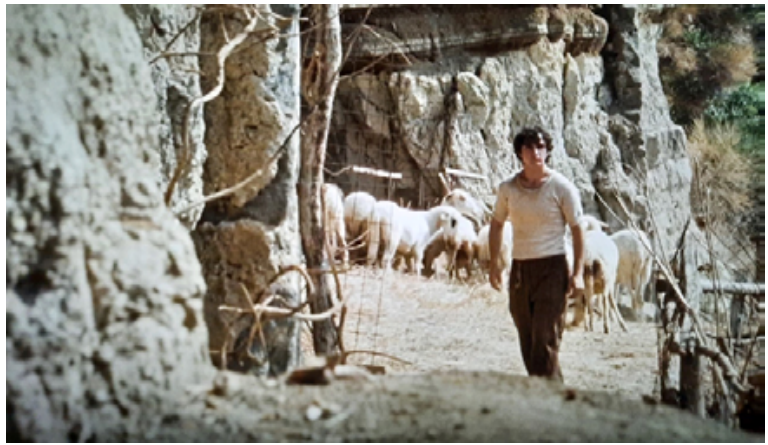

Fig. 19. Lazzaro como representación del Buen Pastor. Fotograma del film.

de Jesús de Nazaret), a quien éste resucita de la muerte. El Lazzaro de Rohrwacher también resucita en la película constituyendo una de las claves fundamentales para la interpretación religiosa del film (el fundamento de la fe cristiana es la creencia en la resurrección y Lazzaro es, sin duda, un santo cristiano). Pero también Lazzaro alude a otro personaje de las Escrituras que aparece en el Evangelio de Lucas (Lc 16, 19-31), en la parábola «El rico Epulón y el pobre Lazzaro»:

Había un hombre rico, que se vestía de púrpura y de lino fino, y hacía cada día banquete con esplendidez. Había también un mendigo llamado Lazzaro, que estaba echado a la puerta de aquél, lleno de llagas, y ansiaba saciarse de las migajas que caían de la mesa del rico; y aun los perros venían y le lamían las llagas...

El paralelismo con el pasaje de Lucas se hace patente en una escena de la película. Tancredi (el rico hijo de la marquesa) pasea ante los campesinos que descansan a la hora de comer. Pese a la arrogancia con que Tancredi mira a sus apareceros, Lazzaro (el joven pobre) le invita a compartir su pan, el joven marqués rechaza 
con desdén el ofrecimiento, pero lo piensa mejor y, con la intención de burlarse de él, le dice que su perro Ercole tiene hambre (la ironía etimológica del nombre del mítico Hércules se hace evidente cuando vemos al minúsculo perro que lleva en los brazos). Lazzaro, ajeno a la malicia del marqués, acerca su pan a Ercole que, tras olfatearlo, se aleja... Sin ofenderse por el agravio del joven rico, Lazzaro le presenta "la otra mejilla» y le ofrece café. De este modo, lo conduce a su pequeño refugio en lo más alto del monte, donde suele ir a descansar, su humilde habitáculo tiene por vecinas a las ovejas (el Buen Pastor que cuida a sus ovejas). Al moderno Tancredi (de cabello oxigenado y ropa estilosa) le parece muy "chulo» el refugio de Lazzaro. Comienza en este momento una bonita amistad entre los dos jóvenes que, como dice Rohwacher, es tan fuerte que atravesará el tiempo.

\section{LA AMISTAD CON TANCREDI, EL REFUGIO DE LAZZARO}

Lazzaro y Tancredi sellan su amistad con un pacto de caballeros, al modo de los antiguos cruzados medievales, que recrea el imaginativo hijo de la marquesa. El nombre de este personaje parece aludir a Tancredo de Galilea, uno de los líderes de la Primera Cruzada católica contra los musulmanes ${ }^{4}$. El joven marqués organiza su propio secuestro y obliga a Lazzaro a unirse al plan urdido por él para pedir dinero a su madre, a la que considera la "enemiga» de los caballeros templarios. De este modo se dirige al joven campesino (don Quijote a Sancho): «Es una zorra explotadora. Se piensa que sois animales. Tenemos que enfrentarnos a ella como caballeros andantes». Y de inmediato se pone a recitar de manera muy teatral unos versos del Orlando Furioso de Ariostó:

¡Oh, gran virtud de antiguos caballeros!

Eran de ley diversa, eran rivales:

Por todo el cuerpo, de los golpes fieros, aún llevan el dolor y las señales.

Y por fragosos bosques y linderos, ¡sin sospechas van juntos y leales!

La amistad con Tancredi es una revelación para Lazzaro, al día siguiente el marqués le entrega el arma (que no es más que un tirachinas) solemnemente: «Yo te entrego esta arma como muestra de nuestra amistad. No la pierdas nunca. Es el arma para enfrentarnos a todos los marqueses del mundo». Lazzaro repite como

${ }^{4}$ Asimismo, Tancredi es el título de una tragedia de Voltaire escrita en 1760 y ambientada en la Primera Cruzada, en la que se basó la ópera homónima de Rossini de 1813.

${ }^{5}$ La relación entre la obra de Cervantes y la de Ariosto ha sido objeto de una amplia reflexión académica en el campo de la literatura. Citamos aquí, a modo de ejemplo, una breve sentencia del Quijote: «Yo - dijo don Quijote- sé algún tanto del toscano y me precio de cantar algunas estancias del Ariosto» (capítulo LxII, segunda parte de El ingenioso cabellero don Quijote de la Mancha, Miguel de Cervantes). 


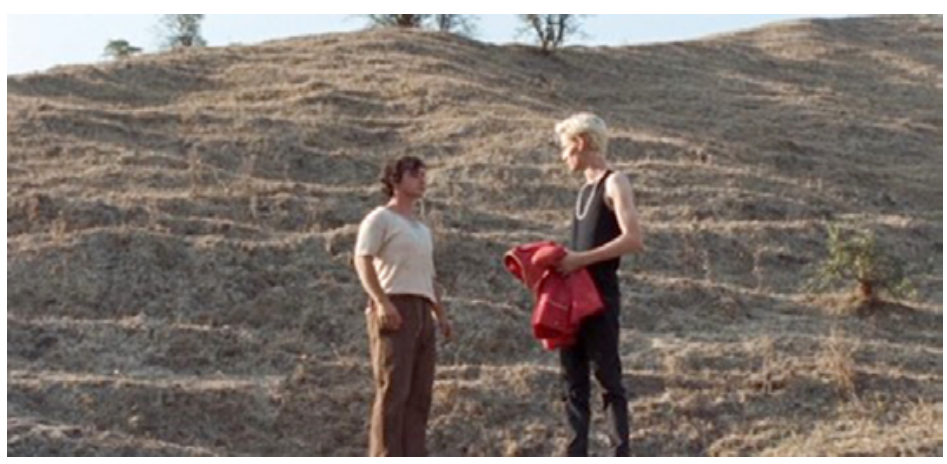

Fig. 20. Tancredi dice a Lazzaro que pueden ser medio hermanos. Fotograma del film.

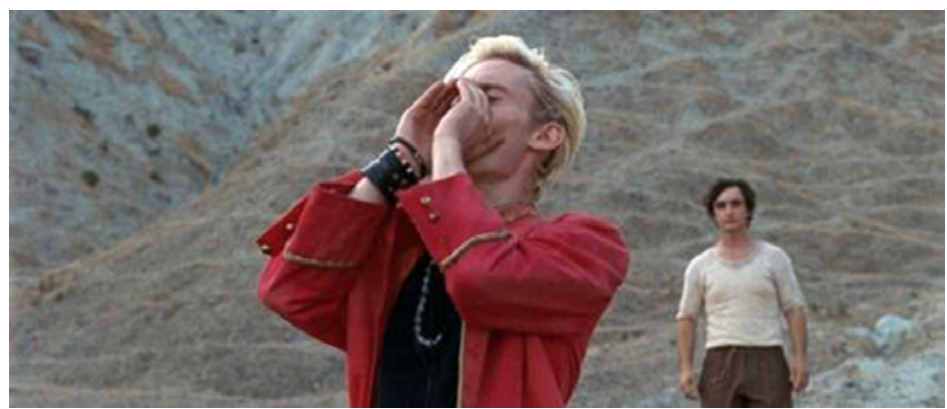

Fig. 21. Tancredi y Lazzaro se divierten imitando el sonido del lobo. Dosier de prensa del Festival de Cannes 2018.

un niño que aprende las palabras por primera vez: «el arma» (anticipo de su trágico final). Más tarde el joven marqués le pregunta por su familia y cuando Lazzaro le responde que no tiene sino a la abuela, el joven dice: «No, ahora me tienes a mí también. No me extraña que fuésemos medio hermanos. Mi padre era un mujeriego». Para el bueno de Lazzaro esto supone una revelación. Ahora adquiere la condición de hermano, en la banda sonora comienza una pieza musical extradiegética (que escuchamos anteriormente en relación con Tancredi) y Lazzaro, en un plano con un ligero contrapicado, mira sonriendo a su medio hermano, que inicia el descenso por una cañada que le parece la luna. Al final del día, ambos jóvenes escuchan al lobo y se entretienen largo rato imitando su sonido.

La relación entre los dos muchachos habría sido improbable en otro contexto. Para Lazzaro es una amistad fabulosa que le descubre un mundo desconocido, su vida hasta ese momento no es más que servir y trabajar como un esclavo. Ahora, junto al imaginativo Tancredi conoce también la aventura, la diversión propia de su edad, la alegría de la adolescencia pasa a ser parte de su vida en Inviolata. 


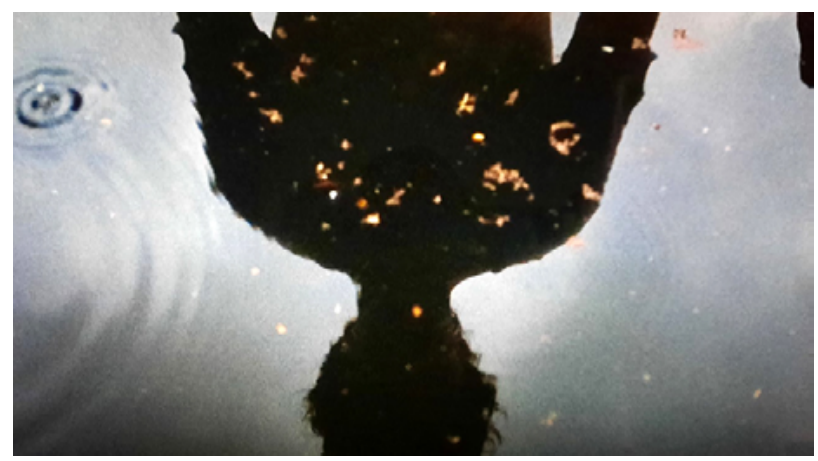

Fig. 22. Imagen de Lazzaro reflejado en el agua del pozo.

Fotograma del film.

Como declara la propia Rohrwacher, el film «habla de una amistad que atraviesa el tiempo». El encuentro entre estos dos jóvenes de distinta procedencia y personalidades tan diferenciadas produce en Lazzaro tal impresión que cuando Tancredi le acusa de no ser un buen hermano porque tiene que ir a trabajar en lugar de quedarse con él, el pobre Lazzaro pasa el día sumido en la desolación. Cuando llega la noche se mira en el agua del pozo, su figura se refleja invertida y oscura (presagio de su muerte), la conmoción es profunda y permanece largo rato de pie bajo la lluvia.

Las niñas de la casa que le ven dicen que se ha vuelto a quedar «atontado» y van a buscarle. Lazzaro tiene fiebre, dicen que se muere. Luego bromean: «Habrá pasado bajo el árbol maldito», dice uno de los jornaleros, o «quizá se está haciendo el inocente», añade con malicia. Luego una de las mujeres dice que tiene que dormir en una habitación, pero viven tan hacinados que todas las camas están ocupadas por cuatro o más personas y no encuentran hueco para él (lo que sugiere que habitualmente no duerme en el interior de la casa). Al final lo acuestan junto a la abuela. A la mañana siguiente, Lazzaro se despierta sin fiebre, se levanta, coge el pan junto a la mesa y emprende el camino en busca de su nuevo hermano. La imagen da paso a otra de Tancredi cogiendo fruta de los árboles. De pronto, se da cuenta de que el móvil tiene cobertura y llama.

En casa de la marquesa, Teresa, la hija de Nicola, está inquieta por no saber de Tancredi, se oye en off la voz de la marquesa dando clase de religión a las niñas: "Aquel que se conoce bien a sí mismo se humilla ante su propia presencia, y las alabanzas de los demás no le causan placer alguno. Si conociera todas las cosas del universo y desdeñara la caridad, ¿quién me proporcionaría la gracia de Dios? ¿Quién me juzgaría por mis actos? Uno debe ir más allá de su sed de conocimiento puesto que distrae y decepciona».

Suena el teléfono, Teresa lo coge. Tancredi dice que entreguen el dinero del secuestro o lo matarán. Voz en off de la marquesa: «¿De qué sirve el conocimiento sin temor de Dios? Un campesino humilde es mejor siervo del Señor que un erudito que se descuida e investiga». Vemos con ironía cómo la marquesa enseña a las 


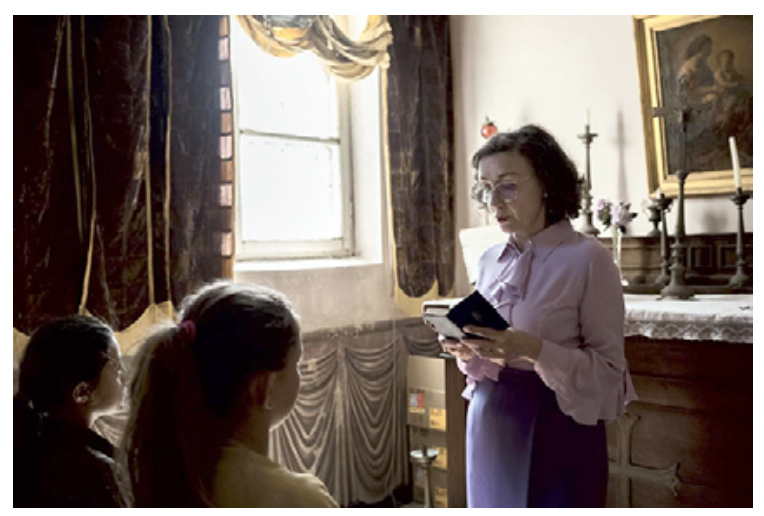

Fig. 23. La marquesa de Luna lee pasajes de las Escrituras a las niñas campesinas.

niñas la virtud de la caridad e incluso afirma que permanecer en la ignorancia es una cualidad. Mientras tanto, ella explota a sus familias manteniéndolas engañadas, viviendo en la miseria y codiciosamente les arrebata alimento y salario. Una acusación directa a cierto tipo de mentalidad católica basada en la hipocresía. Rohrwacher explica la diferencia entre la religiosidad humana y la institucional que quiso reflejar en el film:

En Lazzaro Felice quise poner dos religiones. Una es la religión de los seres humanos, aquella que trabaja por la unificación de la humanidad. Esta unificación no se debe entender en un sentido económico de globalización, sino en un sentido espiritual, como en una especie de fraternidad humana (aunque la palabra fraternidad siempre es peligrosa). Esta religión es fallida, pues no ha podido lograr su cometido, y en ella Lazzaro es un santo que es asesinado una y otra vez, pero siempre regresa. Por otro lado, quería dejar claro que hay otra religión, la religión oficial que es usada por la marquesa para poder dominar a la gente y obtener poder sobre ellos. La marquesa enseña esta religión en la que nunca se trae alimento para la gente, sino, por el contrario, un precio, una deuda. La religión es un instrumento que hipnotiza con sus historias (Atehortúa, 2021).

Al final de la secuencia, Teresa llama en secreto a la policía y le informa de que han secuestrado a un marqués. Se corta la escena y se escucha el sonido de un helicóptero que se acerca a la zona (vista aérea de Inviolata). Tancredi lo oye, mira arriba y sonríe. En ese momento Lazzaro va camino del refugio, oye también el sonido, mira a lo alto, resbala y cae por un precipicio. Cuando Lazzaro cae, escuchamos en off a Antonia narrar la historia de san Francisco y el lobo mientras una cámara subjetiva, que reproduce la mirada del lobo, recorre los escarpados cerros de Inviolata, los campos donde trabajan los campesinos, olfateando, rastreando, buscando a alguien... En paralelo asistimos a la llegada a la aldea del helicóptero y el efecto que producen en uno de los gendarmes las míseras condiciones en que vive 


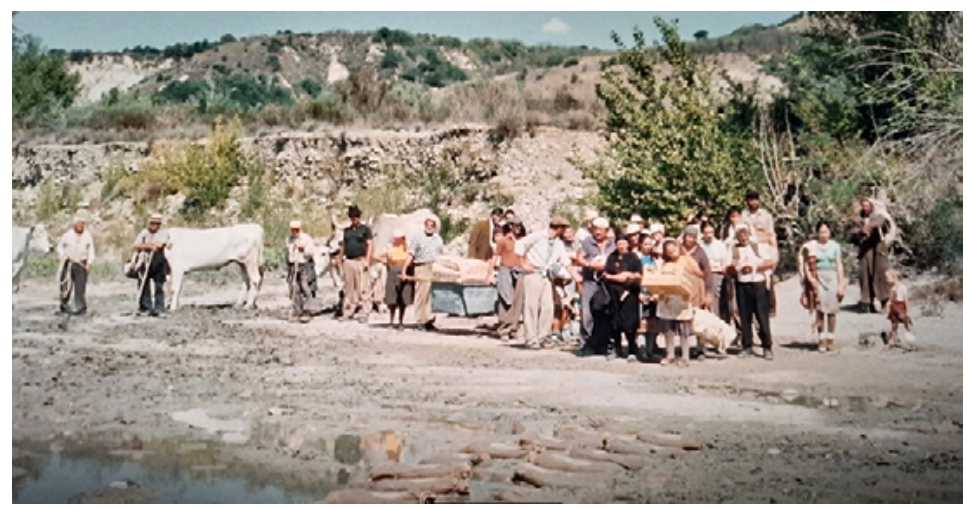

Fig. 24. Los campesinos inician temerosos el éxodo a la ciudad.

Fotograma del film.

aquel medio centenar de aparceros que declaran, entre otras cosas, que pertenecen a la marquesa y que los niños no van a la escuela porque eso es para los ricos. Mientras todo esto sucede y vemos más tarde a los campesinos iniciar temerosos el éxodo forzoso a la ciudad cargados con sus míseras pertenencias y a Antonia preguntando por Lazzaro, la cámara abandona el autobús que traslada a los campesinos y vuelve a la mirada del lobo (en cámara subjetiva) recorriendo los montes. La voz en off de Antonia se escucha de nuevo: «Y llegó el invierno. El santo estaba exhausto, helado y hambriento. Pero no había ni rastro del lobo. No sabía que el lobo también tenía hambre y que llevaba tiempo siguiéndole el rastro. El santo se desplomó en la nieve muerto de cansancio. Entonces, el lobo lo encontró...».

Pasamos a una imagen de Lazzaro tendido en el fondo del precipicio y el lobo que se acerca, lo olfatea. Voz en off de nuevo: «El lobo se acercó, afiló las uñas, y preparó los dientes, listo para devorarlo, pero... De pronto olió algo que nunca había olido, se detuvo, lo olfateó de arriba abajo. ¿Qué era ese olor? Era el aroma de un hombre bueno".

Lazzaro despierta, un resplandor ilumina su rostro, toda la escena aparece iluminada por una luz radiante. La simbología religiosa es patente: Cristo se revela a sí mismo como luz (Jn 8, 12: Yo soy la luz del mundo; el que me sigue, no andará en tinieblas, sino que tendrá la luz de la vida). La cámara se detiene largo rato en la luz que resplandece en el rostro de Lazzaro mientras se incorpora. La luminosidad que muestran todos los planos de la escena actúa como símbolo de la presencia de Dios. Lazzaro ha resucitado. Sabremos, a medida que avanza la narración, que han transcurrido más de veinte años. Lazzaro con idéntica apariencia física, la misma expresión sencilla y la misma candidez de espíritu, como si el tiempo no transcurriera para él, pasa «inalterado» del pasado al presente e inicia su camino hacia el calvario. 


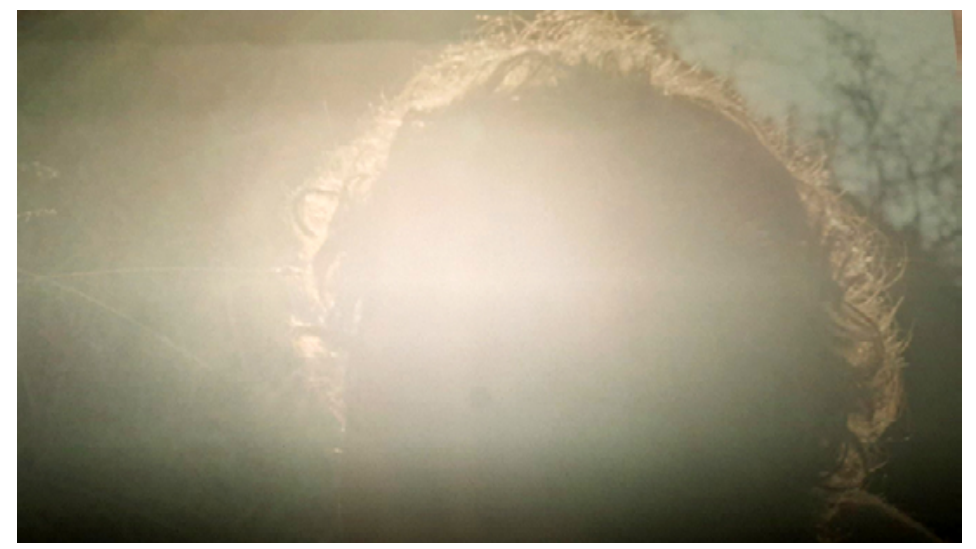

Fig. 25. La Luz brilla en el rostro de Lazzaro resucitado.

Fotograma del film.

\section{LA PASIÓN DE LAZZARO}

Tras descubrir por unos pícaros ladrones (que se encuentran saqueando la casa de la marquesa) que Tancredi se ha marchado, Lazzaro inicia un largo camino en busca de su amigo. Cuando llega a la ciudad se produce un encuentro fortuito con Antonia (ya adulta), quien al ver a Lazzaro con la misma apariencia física que tenía en Inviolata ańos atrás, cree haberse vuelto loca; después de acercarse y comprobar que efectivamente es Lazzaro, se arrodilla ante él y ordena a los que la acompañan (que no son otros que los saqueadores de la marquesa) que lo hagan también. La escena es profundamente conmovedora pero la directora, quizá para romper la solemnidad, le añade una pincelada de humor: los pillos la obedecen de inmediato y el propio Lazzaro lo hace también y se arrodilla, ajeno al hecho de que su presencia es la que origina tal muestra de devoción.

Descubrimos poco después, no sin cierta ironía, que uno de los ladronzuelos es Pippo, el hijo al que Antonia le contaba las vidas de los mártires cristianos. El otro pícaro es Ultimo, personaje que se incorpora en esta segunda parte de la película como novio de Antonia y que interpreta, como habíamos indicado más arriba, el actor español Sergi López. Antonia, pese a las protestas de su novio, decide acoger a Lazzaro y llevarlo con ellos. La secuencia que sigue es una de las más hermosas de la película por su profundidad lírica y su sentido de lo sagrado: construida con la luz del atardecer reflejada en el destartalado carromato, vemos proyectarse las sombras de Lazzaro y Antonia en la lona trasera del vehículo. En la banda sonora vuelve a enmudecer el sonido natural de la escena y sólo se escucha el canturreo de Antonia, que entona una especie de canción de cuna. La pequeña camioneta avanza por la ciudad silenciosa, como flotando en el aire, y en un brevísimo instante, la ligera lona, agitada por la brisa, descubre el interior y nos muestra, como un rayo de luz, la imagen de Antonia y Lazzaro cogidos fuertemente de la mano, unidos fraternal, 


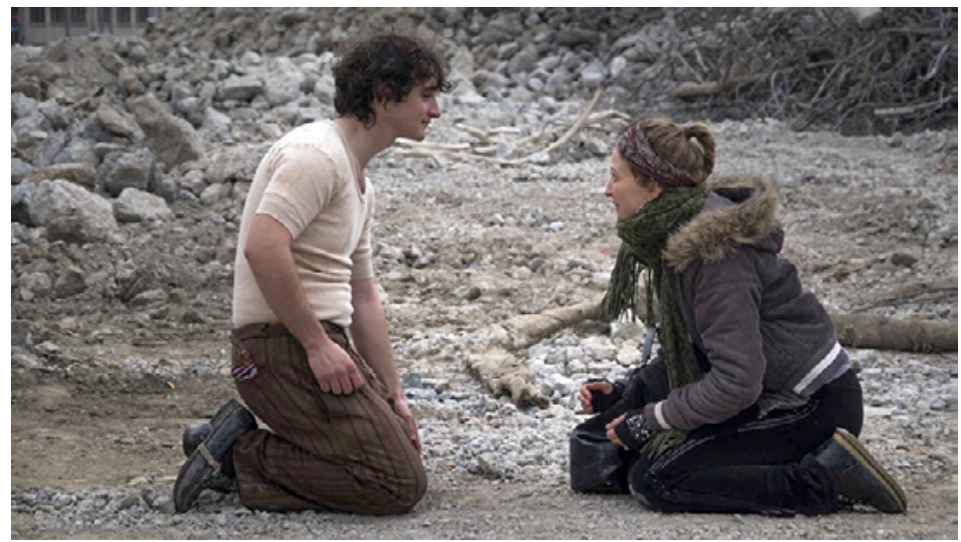

Fig. 26. Antonia y Lazzaro arrodillados en el momento de su reencuentro en la ciudad.

Dosier de prensa, Festival de Cannes 2018.

espiritualmente. Es un momento de recogimiento absoluto, un momento «sagrado». Lazzaro hace su entrada en la ciudad en un humilde y destartalado carricoche (Jesús entra en Jerusalén a lomos de un borrico).

Como habíamos señalado anteriormente, Rohrwacher se vale de una estética muy personal y poética para revelar la presencia de «lo sagrado» en la vida cotidiana de sus personajes, la directora adopta un punto de vista con una enorme carga espiritual para reflejar la naturaleza sagrada de Lazzaro, pero también el idealismo religioso de Antonia. Este personaje femenino (interpretado en su edad adulta por Alba Rohrwacher, hermana de la directora) se caracteriza por dar vida a una joven compasiva y bondadosa, con una enorme sensibilidad espiritual influenciada probablemente por las lecturas religiosas de la marquesa. Desde el inicio de la película, Antonia aparece contando las vidas de los mártires cristianos a su hijo Pippo. También a Lazzaro le cuenta la historia de santa Águeda de Catania (martirizada por el procónsul de Sicilia en el siglo III, en tiempos de las persecuciones contra los cristianos) mientras le muestra su estampa, que, de manera supersticiosa, guarda la marquesa bajo el colchón de la cama. Pero su naturaleza sensible le confiere también una sutil intuición para percibir «algo santo, sagrado» en la persona de Lazzaro. La escena del encuentro con Lazzaro en la ciudad nos muestra la unión que existe entre estos dos personajes, afinidad que se pone de relieve a lo largo de la trama. En esta segunda parte, vemos a Antonia convertida en una mujer adulta que en cierto modo lleva las riendas de la familia y que se dedica, como los demás, a timar a los viandantes para poder sobrevivir en la ciudad. Incluso intenta aprovecharse de la apariencia cándida de Lazzaro para timar a una mujer a la que vende una tabaquera robada en casa de la marquesa. Sin embargo, inmediatamente se nos muestra el arrepentimiento de Antonia cuando Lazzaro, viendo el objeto dentro del bolso, le pregunta con inocencia si no se lo dio a la compradora. Antes de que esto sucediera, Antonia había llevado a Lazzaro a su nuevo hogar, un gran tanque indus- 


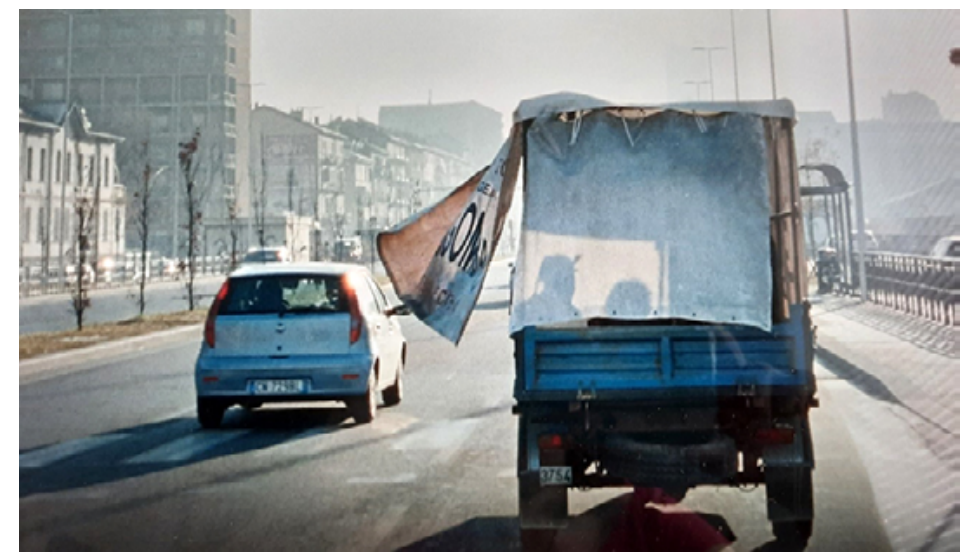

Fig. 27. Imagen poética que muestra las sombras de Antonia y Lazzaro reflejadas en la lona trasera del carromato. Fotograma del film.

trial abandonado junto a las vías del tren en el extrarradio urbano, donde malvive su familia "matando el hambre» con paquetes de patatas chips robadas y viendo la televisión. Un cuadro con estampas de todos los santos parece ser el único vestigio del pasado en Inviolata.

Un lluvioso día invernal Lazzaro prepara manojos de hierbas en las vías del tren cuando aparece Ercole, el perro, ahora maltrecho, de Tancredi. Se oye de lejos a su dueño llamándole, Lazzaro sigue al perro y con regocijo divisa a su amigo, va en su busca, le encuentra bailando en una oscura sala de fiestas. Se acerca, le llama, le dice que es él, Lazzaro, le enseña el tirachinas que selló su amistad en Inviolata y le recuerda que es su hermano, «bueno, tu medio hermano», dice tímidamente. Tancredi (interpretado en su edad adulta por Tommaso Ragno) le mira emocionado y juntos salen a la ciudad. Hacen una visita a los antiguos jornaleros del marqués y celebran una pequeña fiesta por el reencuentro, Lazzaro vuelve a tocar la zampogna, Tancredi, con una cazuela de metal, juega a que es la luna y vuelven a aullar llamando al lobo como aquel verano feliz de la adolescencia, por un instante todos vuelven a ser jóvenes en un juego de planos que muestra imágenes de los niños en Inviolata, y volvemos a escuchar el viento (elemento recurrente en esta película vinculado a Lazzaro y también precediendo los momentos emocionales de los personajes, en este caso los recuerdos de Lazzaro de la vida lejana en el campo). Más tarde, Tancredi dice a todos que debe irse y los invita a almorzar al día siguiente en su casa. Los mendigos se ponen sus mejores galas, compran una bandeja de pasteles muy caros y acuden al domicilio. Teresa, la hija de Nicola, ahora esposa de Tancredi, abre la puerta y tras unos instantes de confusión va a preguntar dentro de la casa, se oye a Tancredi: «Déjame en paz». Teresa vuelve a la puerta y les dice que ha debido haber algún malentendido. Los mendigos se van, Lazzaro se aleja apesadum- 


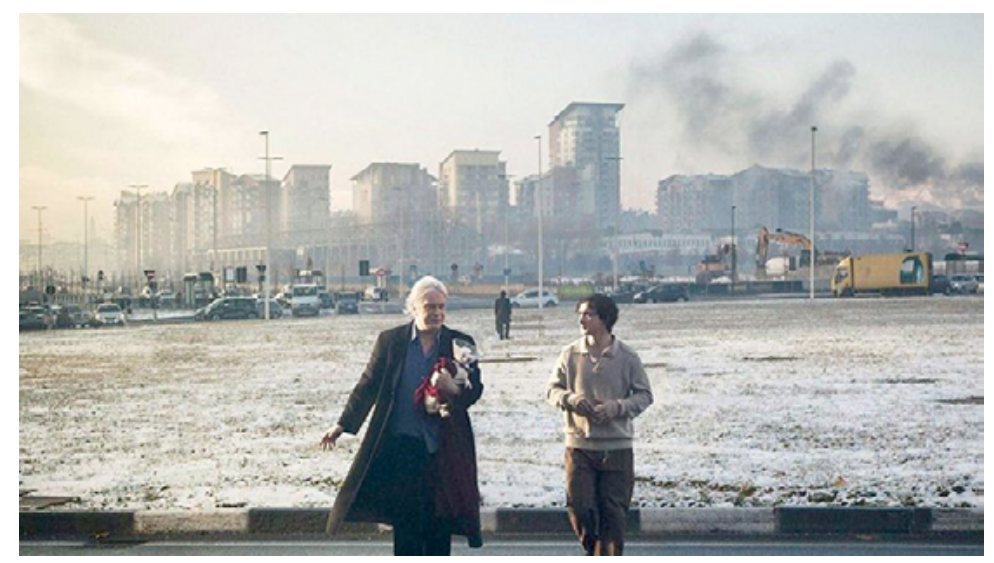

Fig. 28. Reencuentro entre Lazzaro y Tancredi (envejecido) en la ciudad. Fotograma del film.

brado. Teresa vuelve a llamar. Ahora Lazzaro sonríe animado y exclama: «iEra una broma!». Pero se equivoca. Teresa les suplica que le dejen los pasteles. Ante las protestas de los demás, Antonia compadecida se los da y le pregunta cómo han llegado a esa situación. Teresa grita: «Ha sido la banca, son unos monstruos, nos lo quitaron todo. Y no nos queda nada. Son unos estafadores». Lazzaro repite para sí: «la banca».

Vemos ahora el plano de las manos de un músico que toca el órgano. Luego otro de Lazzaro en la calle, que escucha la música profundamente emocionado; en segundo término, los mendigos intentan arrancar la camioneta, que se ha averiado. Antonia se acerca a Lazzaro y le dice: "¿iTe gusta? ¿Quieres ir a escucharla?». "Síı,, responde Lazzaro. Y se dirigen todos a la iglesia de donde proviene el sonido del órgano. Entran, se persignan y, de pronto, una monja que advierte su presencia se acerca corriendo y les dice: «No, no, no». «No pueden estar aquí, tienen que irse. Es una función privada. Márchense, por favor». «Sólo queremos oír la música», dice Antonia...». «En otra ocasión, váyanse por favor». "No molestamos a nadie», insiste Antonia. El organista se levanta a ver qué ocurre, vemos un plano de Lazzaro, la monja le dice que se vaya también. Antonia le llama. Luego la monja dice «Carlo, comienza de nuevo». Éste empieza a tocar y las teclas no emiten sonido. Escuchamos de nuevo el sonido del viento, sabemos que va a ocurrir algo... Entonces se oye la música, emerge de ninguna parte, autónoma, con entidad propia, adquiere casi una cualidad física. Las monjas miran a lo alto sobresaltadas, una de ellas grita: «¿Adónde va? ¡Se marcha! ¡La música se va! ¡Cerrad la puerta!». La escena presenta una palpable crítica a ciertas actitudes del clero católico que se considera propietario de la casa de Dios.

Pero sigamos a nuestros mendigos, que, expulsados del templo, vuelven a empujar el carromato averiado. Hacen un pequeño descanso y de pronto escuchan 


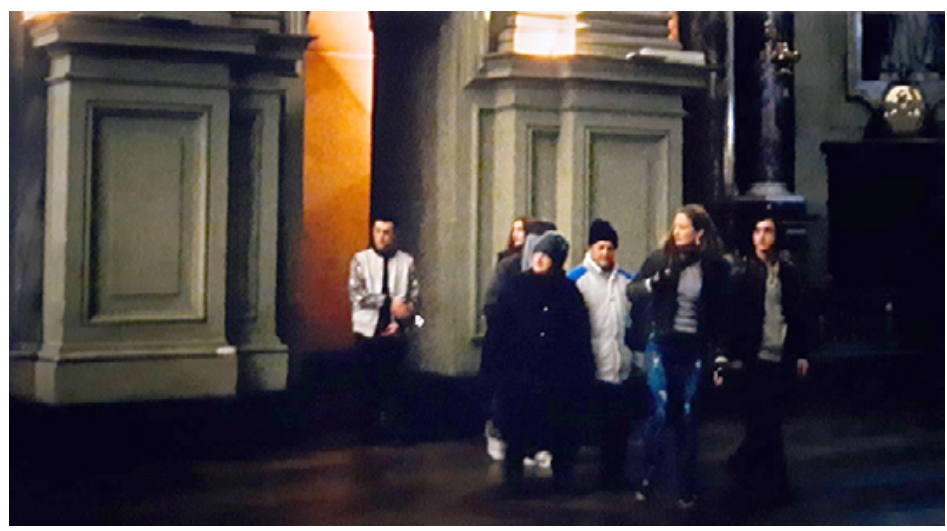

Fig. 29. Los mendigos entran en la iglesia a escuchar la música del órgano. Fotograma del film.

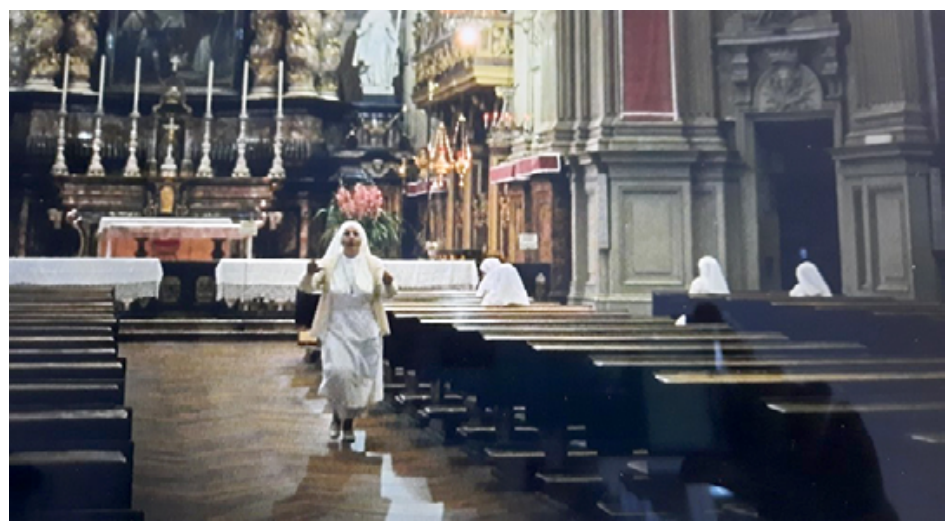

Fig. 30. La monja ordena a los mendigos que abandonen la iglesia. Fotograma del film.

la música: «¿Lo oís?», dice Antonia, «iLa música! ¿De dónde viene? ¡La música! ¡Nos sigue!». Todos miran al cielo sonriendo... "Va por el cielo», dice el anciano campesino. Vemos a Lazzaro ensimismado. La música sigue sonando sobre ellos y de nuevo intentan echar a andar el vehículo. Lazzaro deja de seguirlos.

La película nos muestra cómo después de ser expulsados del templo, la música del órgano sale de la iglesia tras los mendigos, tras Lazzaro. La música diegética sale del marco que le corresponde en la narración y corre tras los personajes. Un hallazgo estilístico intensamente conmovedor. Como ya hemos señalado, mediante el lenguaje visual y sonoro se crea una nueva imagen simbólica, se otorga 


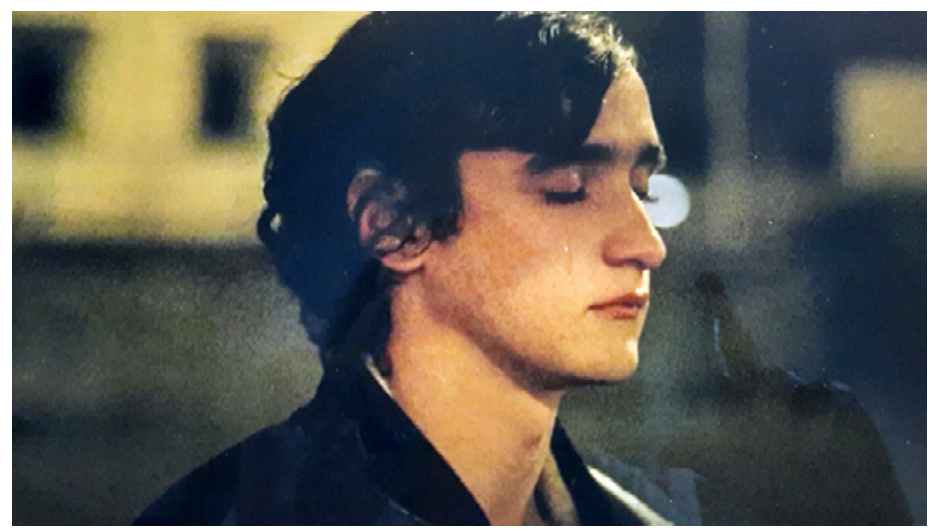

Fig. 31. Lazzaro como el Siervo sufriente de Dios.

Fotograma de la película.

a la escena una carga lírica en medio de la narración realista que la trasciende para presentarnos una idea sublime: la música religiosa, «lo sagrado», abandona el lugar al que supuestamente pertenece (la iglesia) y corre hacia quien es más digno de ella, Lazzaro. La propia directora manifestó la finalidad de esta escena:

Para mí era importante que la música se fuera con Lazzaro, porque si ella tiene que estar con alguien, debe ser con él. Dándole vida autónoma a la música, ella se vuelve algo físico, algo que se puede tocar (Atehortuá, 2021).

Mientras Lazzaro se queda atrás, los campesinos siguen empujando el carricoche y hablan entre ellos de volver a la aldea: «Oye, ¿tú te acuerdas de Inviolata?», dice Pippo. «No, era muy pequeña», responde Estefanía. «Si aquello está abandonado, ¿por qué no volvemos y nos hacemos con el control?», propone Pippo, y añade "iHasta tenemos las llaves!». Antonia dice: «No podemos, no es nuestro». Su hijo contesta: «Siempre te quejas de que lo construiste con tu esfuerzo y tu sudor. Podríamos asentarnos allí, pero sin patrones». «¿Sin patrones?», pregunta el anciano.

«Pausa», grita Antonia, y se detienen. Pippo continúa: «iSería genial!». Su madre le dice: "La música te ha dejado atontado», y entonces repara en que Lazzaro no los ha seguido. Pipo le llama. Lazzaro se ha quedado parado en medio del camino. «`Ven!», grita Pippo, pero Lazzaro no se mueve. Antonia dice: «Déjale en paz. Ha sido un golpe duro para él, vamos» y emprenden el camino. «Ya nos seguirá él», añade Antonia, y pregunta a su hijo: «¿Quieres volver a Inviolata?». Pippo responde: «Sí, ¿no te alegra?». Todos ríen. "Quiere volver al campo para labrar la tierra», dice Antonia. Las voces se alejan.

Vemos a Lazzaro sufrir injustamente, el inocente ha sido traicionado por su amigo (Judas); también quizá por presenciar cómo se ha "profanado» la Casa de su Padre (la iglesia "farisea» ofrece conciertos privados en el templo). Lazzaro se ha 


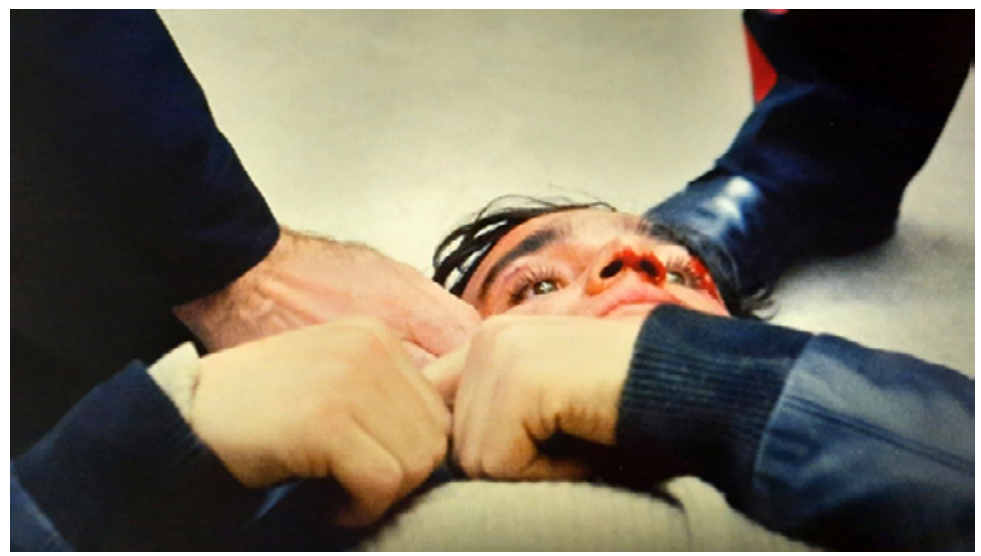

Fig. 32. El Cordero de Dios ha muerto apaleado por la gente.

Fotograma de la escena final del film.

transformado, ya no es Lazzaro Felice. En el frío de la ciudad se dirige hacia unos árboles al borde del camino, seguimos escuchando la música del órgano y a lo lejos, las risas alegres de los campesinos. Lazzaro mira a lo alto. Una radiante luz se refleja en un árbol, la naturaleza manifiesta nuevamente la presencia divina ${ }^{6}$. Lazzaro acaricia la hierba, (recuerda Inviolata), después se sienta. Un primer plano nos muestra su rostro afligido, cierra sus ojos tristes, una lágrima desciende por su mejilla. Una sombría y honda desolación le embarga y siente el alma triste hasta la muerte (Jesús en Getsemaní, Mt 26, 38: Mi alma está triste hasta la muerte). La dolorosa escena se corta con un plano de la luna.

Corte y la acción se traslada a la mańana siguiente. Lazzaro entra en la sucursal de un banco, hay una cola de gente, él se adelanta, pide que le devuelvan sus propiedades al marqués de Luna, alguien ve el bulto del tirachinas en su bolsillo y cree que es una pistola... La banda sonora anticipa la tragedia, se escucha Erbarme dich mein, O Herre Gott (Ten piedad de mí, Señor, Salmo 51), de Johan Sebastian Bach. La gente de la cola se abalanza sobre el inocente y le golpea furiosa. El «sacrificio» de Lazzaro remite claramente a la pasión y muerte de Jesús. Lazzaro muere apaleado e insultado por los clientes de la sucursal bancaria ${ }^{7}$ sin llegar a saber lo que ocurre;

${ }^{6}$ Greeley afirma que, a diferencia del pensamiento protestante, judío e islámico, que ven una radical discontinuidad entre Dios y el mundo, la sensibilidad religiosa católica ve el conjunto de la creación como una metáfora: todo es gracia (Greeley, 1988, p. 94).

7 Rohrwacher declara sobre la muerte de Lazzaro: «El capitalismo como religión es quizá el gran problema del presente. Al final de Lazzaro Felice el protagonista es asesinado por los propios pobres. Es como si la marquesa, o quien los explota, no necesitara defenderse más, pues son los propios explotados quienes defienden a los ricos. Para mí era importante que al final de la película fuera 


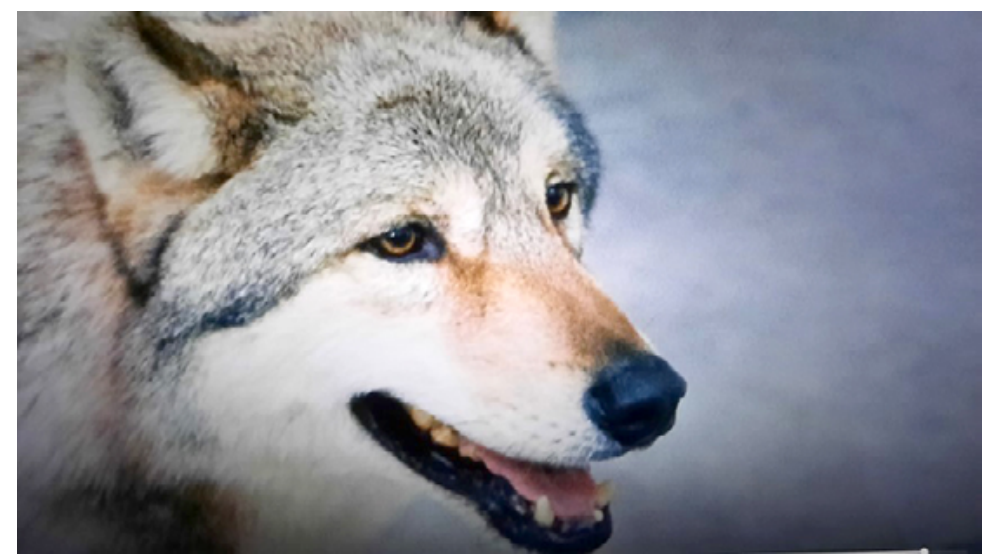

Fig. 33. El lobo, testigo de la muerte de Lazzaro.

Fotograma del film.

los golpes que recibe Lazzaro también los recibimos nosotros como espectadores. El Cordero ha muerto, el sacrificio, anticipado por Antonia en los relatos de mártires cristianos, se ha consumado. La imagen de la muerte de Lazzaro representa una cruz que se forma con sus manos sobre el pecho, el pie de un policía y la mano de otro, en clara alusión a la crucifixión de Cristo.

La carga emotiva y trágica se acentúa con la entrada en la escena del lobo, que asiste como testigo silencioso a la muerte de Lazzaro maltratado por los hombres (Jn 18, 23: «ppor qué me golpeas?»). El hermano lobo de Francisco de Asís que, tras verle en el suelo masacrado, sale del banco y se aleja corriendo por la ciudad en el último plano de la película. Este final no es del todo pesimista, ya que el plano del lobo puede sugerir la resurrección de Lazzaro y, por tanto, la resurrección de Cristo y la esperanza de una vida nueva. Analizamos esta idea con mayor detalle: el lobo está presente en toda la película desde el inicio, igual que el protagonista: primero se percibe como amenaza para los campesinos con la aparición de la gallina y la guardia del lobo, después escuchamos varias veces sus aullidos, más tarde, ya haciendo visible su presencia, es el amigo de Lazzaro (de Asís). El lobo se acerca por primera vez a él, en su muerte en el precipicio, allí siente el «aroma» de su santidad, el lobo simboliza entonces «lo espiritual» y se podría ver como un doble del héroe. Lazzaro no teme al lobo, incluso en la escena en que él y Tancredi escuchan sus aullidos en las montañas de Inviolata, Lazzaro dice: «¿Qué dirá? Es como si llamara a alguien»... Por si fuera poco, hay un plano en la película en el que aparece reflejada en el rostro

la gente normal la que matara a Lazzaro simplemente por la sospecha de que podían llegar a perder algo de lo poco que les queda» (Atehortúa, 2021). 


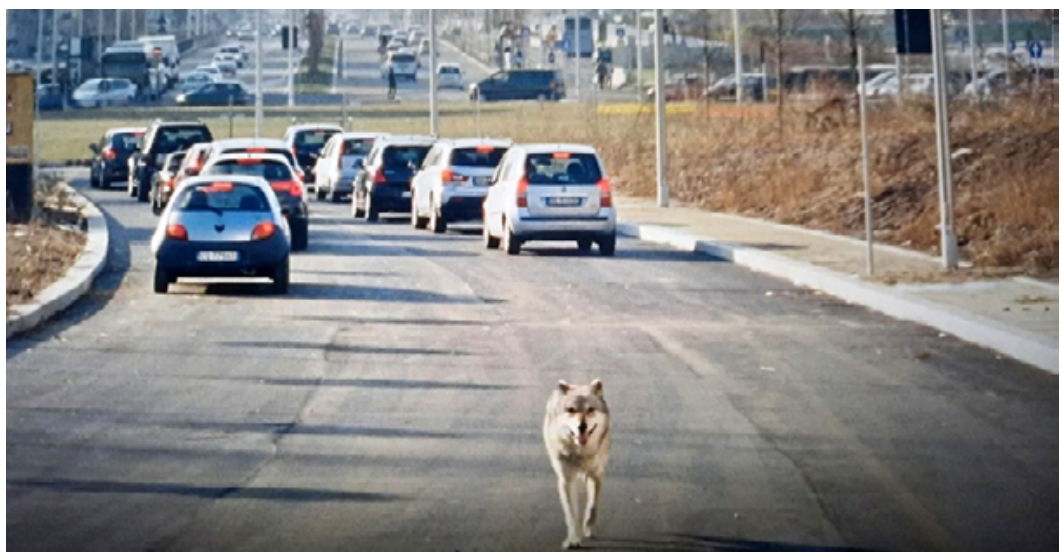

Fig. 34. El lobo se aleja de la ciudad tras presenciar la muerte de Lazzaro. Fotograma del film.

de Lazzaro la sombra del rostro de un lobo (como aparece en los juegos infantiles de sombras chinescas) y en algunas escenas Lazzaro "mira» como un lobo, como si se nos quisiera mostrar esa posible dualidad del personaje. El lobo, que en el medievo era símbolo de un tiempo destructor, de la muerte y el renacimiento, pero también "portador de la cruz», está junto a Lazzaro en el momento de su segunda muerte. Tales indicios nos llevan a pensar que esa imagen final del lobo, corriendo en sentido contrario a los coches, es Lazzaro que vuelve de nuevo. Rohrwacher declara que, con la muerte de su protagonista, quiso expresar «lo que pudo ser y no dejamos que fuera», porque volvimos a «matar a Dios». Pero también, ese plano final del lobo que se aleja de la ciudad y corre, quizá tras los campesinos de Inviolata, representa la resurrección de Lazzaro (de ahí el nombre del protagonista y del film). El final se nos presenta como una invitación a inventar una nueva humanidad, a recuperar la pureza perdida que representa Lazzaro, que representa la fe cristiana.

El plano del lobo corriendo funde a los créditos finales y en la oscuridad escuchamos el sonido de los grillos y de las ranas entremezclados con las voces y risas de los campesinos. La película termina en la oscuridad igual que empezó, el círculo (símbolo de lo divino) se cierra y escuchamos una canción: Il tuo sguardo verso il cielo / è per noi il sentiero / Corri Lazzaro corri / Noi siamo con te (Tu mirada al cielo es nuestro camino, corre Lazzaro corre, estamos contigo). Alice Rohrwacher deja una ventana abierta a la esperanza. Lazzaro es el camino, una fuerza del pasado que retorna una y otra vez porque el Bien no puede ser exterminado:

En Lazzaro Felice sucede lo mismo, al final hay un lobo que corre a través de la ciudad y los coches no lo notan. ¿Hacia dónde se dirige? ¿Por qué lo hace? Para mí es muy importante crear estas imágenes que puedan dejar en la gente esa energía de que algo nuevo está por empezar [...]. Mucha gente ha visto Lazzaro felice como 


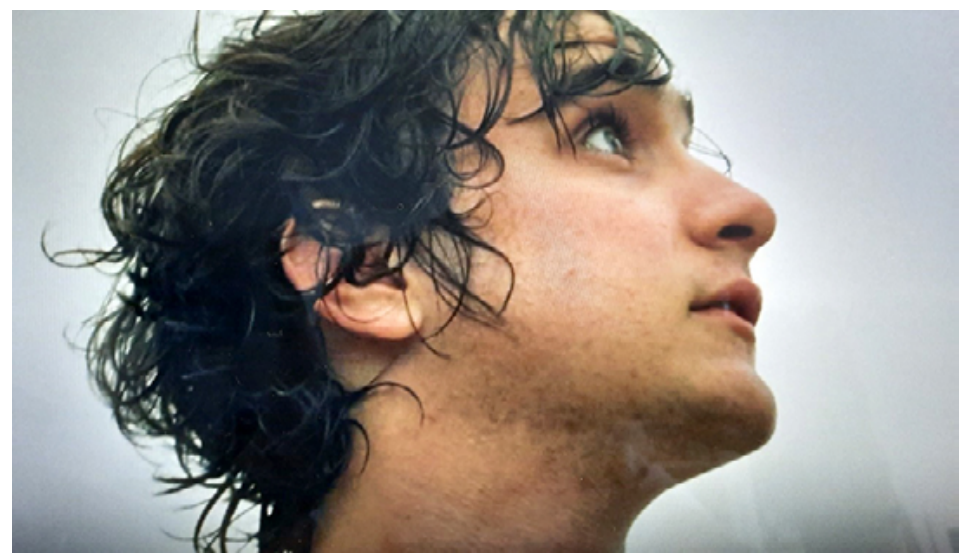

Fig. 35. Lazzaro en una imagen previa a su muerte que recuerda las representaciones de Cristo con la corona de espinas. Fotograma del film.

una película pesimista, y es cierto que puede ser interpretada así, pero como sabemos Lazzaro puede resucitar, y es nuestra responsabilidad, la próxima vez que él aparezca, no permitir de nuevo su muerte [...] Lazzaro es una fuerza del pasado que retorna y retorna porque no puede ser exterminada [...]. Para mí eso es lo que representa el lobo del final que corre en medio de la autopista sin que los coches lo noten (Atehortúa, 2021).

Con un estilo propio, sin agotar la realidad social y política que nos presenta o a través de ella, Alice Rohrwacher logra establecer una conexión espiritual con el espectador. Su finalidad es comunicar, hacernos reflexionar, buscar sentido a la existencia. Sitúa la acción en un escenario rural y más tarde en un escenario del extrarradio urbano donde a través de un personaje que atraviesa el tiempo podemos percibir la verdad, el misterio de la fe, como ella misma expresa: «Una película religiosa donde no hay ninguna religión oficial, sino que es sobre la fe, sobre el martirio y sobre aquello que no podemos ser, pero sí podemos reconocer» (Atehortúa, 2021). La directora reflexiona sobre el lado espiritual de la existencia, sobre el mundo interior que une a todos los seres humanos y propone encontrar en esa conexión la alternativa a una sociedad que ha convertido el capitalismo feroz e inhumano en su nueva religión. Rohrwacher nos invita a emprender una trayectoria diferente, nos invita a reconocer en Lazzaro (Cristo) el único camino "verdadero», y lo expresa en su película a través de la poesía de lo cotidiano, del simbolismo de las imágenes y de la mirada pura de su hermoso Lazzaro.

Reconozco el poder que tienen los símbolos como formas que posibilitan el contacto de dos niveles diferentes de la esencia del ser. El símbolo es la posibilidad que adquiere una imagen de alcanzar un nivel más elevado de la experiencia. Si uno hace películas, como las hago yo y muchos otros cineastas, de algún modo uno está 


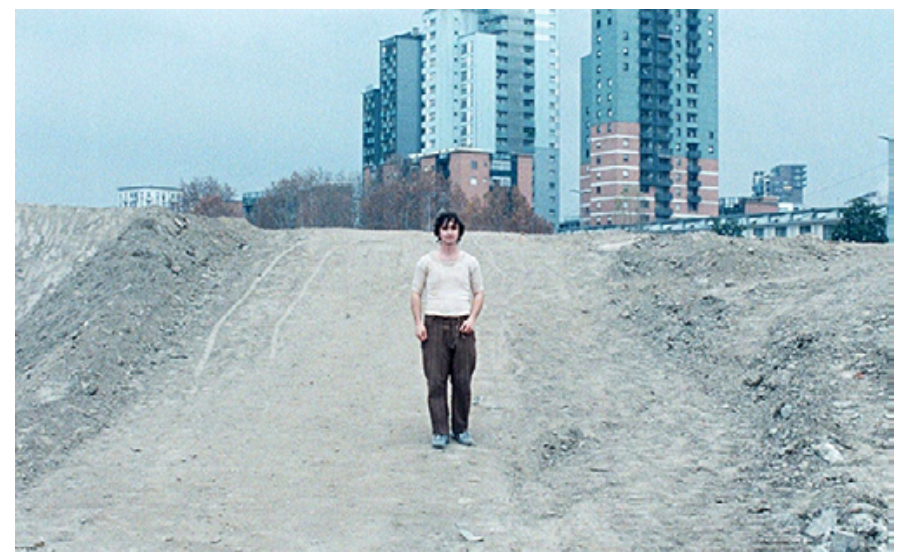

Fig. 36. Lazzaro llega a la ciudad en busca de sus amigos.

Fotograma del film.

siendo una persona religiosa porque está teniendo fe en el poder de las imágenes para abrir y tocar algo más allá de la experiencia (Atehortúa, 2021).

RECIBIDO: 22-6-2021; ACEPTADO: 19-7-2021 


\section{REFERENCIAS}

Andi, A. F. (2019). Lazzaro Felice üzerine bizimkisi bir büyübozumu hikâyesi, Kültur Atlasi, n. ${ }^{\circ} 96$.

Atehortúa, J. (2021). Los cines por venir: Diálogos con autores contemporáneos, Barcelona: Planeta de Libros.

Belinchón, G. (2018, 14 de mayo). "Alice Rohrwacher, ¿̨la segunda cineasta en ganar la Palma de Oro?», El País.

Biblia de Jerusalén (2019). Bilbao: Desclée de Brouwer.

Bird, M. (1982). «Film as Hierophany», Religion in Film (pp. 3-22), University of Tennessee Press: ed. May and Bird.

Cavalcanti, H. (2020). «O homem é o lobo do homem: Hobbes e a natureza humana em Lazzaro Felice», Cinema \& Humanidades: Ensaios multidisciplinares, vol. 2.

Di Bianco, L. (2020). «Ecocinema Ars et Praxis: Alice Rohrwacher's Lazzaro Felice», The Italianist. https://doi.org/10.1080/02614340.2020.1764726.

Díez de Velasco, F. (2008). Breve historia de las religiones, Madrid: Alianza.

Louvart, H. (14 de mayo de 2018). La directrice de la photographie Hélène Louvart, AFC, parle de son travail sur Lazzaro Felice, d'Alice Rohrwacher. Association Française des directeurs de la Photographie. https://www.afcinema.com/La-directrice-de-la-photographie-Helene-Louvart-AFC-parle-de-son-travail-sur-Lazzaro-felice-d-Alice-Rohrwacher.html?lang=fr.

Eliade, M. (2014). Lo sagrado y lo profano, Barcelona: Paidós.

Fernández, F. (2018, 8 de noviembre). Entrevista: «Hablamos con Sergi López, el actor español que aparece en Lazzaro Feliz, la aclamada película de la italiana Alice Rohrwacher», Fotogramas. https:/www.fotogramas.es/noticiascine/a24788029/lazzaro-feliz-sergi-lopez-entrevista/.

FöLdÉNyi, L. F. (2004). El sudario de la Verónica, Barcelona: Galaxia Gutemberg, Círculo de Lectores. Greeley, A. (1988). God in Popular Culture, Chicago: Thomas More.

Guardiola, I. (2019). «Al.legories cinematogràfiques per pensar Europa», Revista Idees, 46, Barcelona: Centre d'Estudis de Temes Contemporanis.

Holmevist, J. (2018). «The ambition that drives Lazzaro Felice», Segmento.

MaY, J. (1982). «Visual Story and the Religious Interpretation of Film», Religion in Film (pp. 23-43), University of Tennessee Press: ed. May and Bird.

MaY, J. (1998). La nueva imagen del cine religioso, Universidad Pontificia de Salamanca.

Mizzi, M. (1999). El mensaje de San Francisco, Madrid: Celeste ediciones.

Nuevo Testamento (2002). Madrid: San Pablo.

Orellana, J. (2004). Como en un espejo, Madrid: Ediciones Encuentro.

PAst, E. (2019). Lazzaro felice by Alice Rohrwacher, GSI (Gender, Sexuality, Italy).

Ratzinger, J. (papa Benedicto XVI) (2007). Jesús de Nazaret, Madrid: La Esfera de los Libros.

Rondini, A. (2018). «Strategie e risultati del Piano B. L'agency nel cinema italiano contemporáneo», Cinergie-Il cinema e le altri arti, n. ${ }^{\circ} 14$.

Sola Antequera, D. (2012). «La pasión de Jesús en el cine contemporáneo», en La verdadera historia de la Pasión según la investigación y el estudio histórico. Madrid: Edaf. 
SAIto, S. (2018). Interview: «Alice Rohrwacher on Creating a Timely and Timeless Tale with 'Happy as Lazzaro" The Moveable Fest.

Tempesta Film (2018). Happy as Lazzaro press kit. 